\title{
Det sønderjyske pengeinstitutlandskab siden 1968
}

\author{
Af Mogens Asmund
}

Erhvervsstrukturerne forandres løbende, og over en blot lidt længere årrække er ændringerne markante. Det gælder også på finansområdet. I Sønderjylland er pengeinstitutlandskabet således i løbet af de små 40 år, hvor landsdelen udgjorde én amtskommune, blevet et helt andet. Af de 52 pengeinstitutnavne, man i 1968 kunne møde rundt om i Sønderjylland, kan kun ét genfindes blandt de 16, der er repræsenteret $\mathrm{i}$ dag. $\mathrm{Og}$ antallet af bemandede betjeningssteder til rådighed for sonderjyderne er mere end halveret til ca. 100. I denne artikel fortælles en del af historien om de sønderjyske banker, sparekasser og andelskasser i nyere tid.

I 1968 var pengeinstitutlandskabet i Sønderjylland endnu karakteriseret ved mange, typisk mindre, selvstændige, lokalt forankrede banker og sparekasser. Der var på det tidspunkt 29 sparekasser og 11 banker - plus en håndfuld andelskasser - med domicil i Sønderjylland, og de lokale institutter var repræsenteret med over 150 bemandede betjeningssteder ${ }^{1}$ i landsdelen. Hertil ca. 60 filialer af syv institutter med hjemsted uden for Sønderjylland - væsentligst filialer af københavnske hovedbanker ${ }^{2}$. De flere end 200 betjeningssteder var fordelt på 100 sønderjyske lokaliteter. På nogle få pladser, primært købstæderne, var der op til en halv snes pengeinstitutafdelinger. Men det typiske var, at der i hver by eller sogn var en enkelt eller højst et par afdelinger - og mange steder var den lokale, selvstændige sparekasse alene på pladsen.

Landsdelens situation på pengeinstitutområdet i 1968 kan karakteriseres som en forholdsvis fredsommelig markedsdeling uden voldsom konkurrence institutterne imellem. Den adskilte sig således ikke fra forholdene i det øvrige Danmark.

Men 1968 var ikke kun det år, hvor ungdomsoprøret for alvor brød løs. Det var - uden sammenligning i øvrigt - også året, hvor en total nytegning af det sønderjyske pengeinstitutlandkort gik i gang. 
Figur 1: Selvstændige sønderjyske pengeinstitutter anno 1968

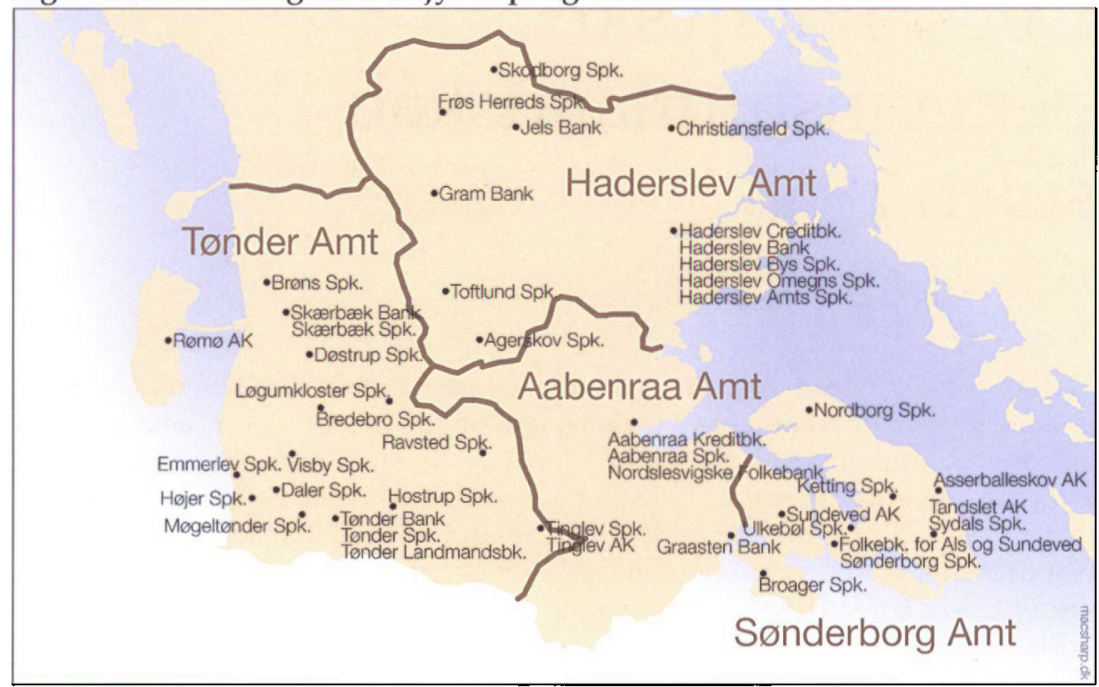

På kortet ses placeringen af de 45 selvstændige lokale pengeinstitutter, der, tillige med syv institutter med hjemsted uden for landsdelen, opererede $i$ Sonderjyllands-området $i$ 1968. Fordelingen af selvstændige sonderjyske institutter på de gamle amter var meget ujæun: 19 i Tonder, 12 i Haderslev, 10 i Sonderborg og fire $i$ Aabenraa. Til gengæld var den amtsvise fordeling af $i$ alt 221 bemandede betjeningssteder mere ligelig: $60 i$ bade Tonder og Haderslev, 55 i Sonderborg og 46 i Aabenraa. De fulde navne pa de dazærende lokale pengeinstitutter fremgår af bilagstabellerne.

Syv år senere - i 1975 - var antallet af selvstændige sønderjyske banker og sparekasser reduceret drastisk: fra 40 til 11. Det afspejler en forandringstendens på pengeinstitutområdet, som i disse år prægede hele landet - og mange dele af samfundslivet ${ }^{3}$. De større institutter, der kom ud af konsolideringsbølgen omkring 1970, gik i mange tilfælde også ud over deres hidtidige geografiske landsdels-virkefelter. I første omgang var denne trafik dog for Sønderjyllands vedkommende ensrettet - udefra og ind. Det havde for det sønderjyske pengeinstitutlandkort den konsekvens, at antallet af institutter med hjemsted uden for amtet næsten fordobledes i perioden 1968-75 - fra syv til 12. Uanset koncentrationen på færre selvstændige enheder gik udviklingen $i$ antal bemandede betjeningssteder til rådighed for befolkningen den modsatte vej og nåede $i$ løbet af 1970'erne et toppunkt omkring 240. Vel var der altså tale om en dramatisk koncentration, reduktion og omstilling, hvad angår antallet af lokale aktører og der- 
med de sønderjyske navne på skiltene - men slet ikke om en rationalisering af leverancesystemet.

Den næste markante omvæltning i det danske pengeinstitutlandskab fandt sted i perioden 1989-94. Seks store landsdækkende institutter blev til de to mega-banker Den Danske Bank og Unibank, og i samme periode bukkede flere regionale institutter under. I Sønderjylland gik de to dominerende lokalt baserede institutter, Sydbank og Sparekassen Sønderjylland, i 1990 sammen til Sydbank Sønderjylland. Med denne lokale fusion og med baggrund i sammenlægningen af hovedbanker, der filialmæssigt hver især var ganske vel repræsenterede i landsdelen, blev der bl.a. skabt grundlag for gennemførelse af den rationalisering af leverancesystemet, som kun forsigtigt var igangsat i løbet af 1980'erne. I 1997 var der 15 banker og sparekasser tilbage i Sønderjylland, heraf otte lokalt domicilerede. Antallet af betjeningssteder var næsten halveret - til godt 120 .

I det seneste tiår er antallet af banker og sparekasser med repræsentation i Sønderjylland yderligere reduceret til 13, heraf seks med hjemsted i landsdelen, og antal bemandede betjeningssteder er nu nede omkring 100. Det skal bemærkes, at det meste af tiåret - til og med 2007 - var karakteriseret ved udtalt medvind for finansbranchen, hvilket betød, at de største bankers fortsatte filialrationalisering delvist blev opvejet ved mindre institutters aktive nyetableringsadfærd.

Denne artikel forfattes og afsluttes på et tidspunkt, hvor de danske pengeinstitutter er ramt af den såkaldte finanskrise. Hvor omfattende forandringer, det vil føre med sig, er uvist. Men det kan meget vel blive voldsomt. En del mindre og mellemstore pengeinstitutter har således i det seneste år opgivet selvstæendigheden, herunder også et sønderjysk. Historien herom skal nok blive skrevet.

\section{Formål, struktur og metode}

Nærværende artikel er en undersøgende og kommenteret beskrivelse af det sønderjyske pengeinstitutlandskab og forandringerne heri i perioden siden 1968 - naturligt med afsæt i forhistorien og den generelle samfunds- og finansudvikling. Der konkluderes med bud på, hvorfor det gik, som det gik, på pengeinstitutområdet i Sønderjylland.

Pengeinstitutter (institutter) er samlebetegnelse for banker og sparekasser. Hvor det eksplicit anføres, inddrages også andelskasser. Be- 
skrivelsen af udviklingen baserer sig alene på antal institutter og disses filialer (bemandede betjeningssteder). Det enkelte instituts filialantal antages - næppe helt urealistisk - at afspejle instituttets relative størrelse. Gængse styrkemæssige målestørrelser som kapital, forretningsomfang, indtjening, kundeantal og beskæftigelse anvendes ikke, bl.a. fordi specificerede data herom ikke foreligger i sammenlignelig form.

Sønderjylland er her den amtskommune, der, i hovedtræk omfattende de gamle nordslesvigske amter, Haderslev, Tønder, Aabenraa og Sønderborg, kom til verden i 1970 og forsvandt igen 37 år senere ved den offentlige strukturreform pr. 1. januar 2007. Med denne geografiske afgrænsning tilgodeses en ambition om at bidrage med et stykke nutidig, bred finansiel historieskrivning om det Sønderjylland, der nu ikke længere har nogen formel eksistens.

Den behandlede tidsperiode har som foran anført baggrund $i$, at der netop i slutningen af 1960'erne også i den danske pengeinstitutverden startede en skelsættende, regionalt stordriftsinspireret og grænseoverskridende, strukturændringsproces. Statistisk følges udviklingen helt frem til august 2009; men der kommenteres primært på periodens første del.

Forfatteren har været en del af systemet gennem det meste af perioden - i årene 1983-2008 som ansat i Sydbank.

\section{Forhistorien: De sønderjyske pengeinstitutter 1920-1968}

Historien om det nutidige pengeinstitutlandskab i Sønderjylland og ændringerne over tid heri må nødvendigvis indledes med at trække linjerne tilbage. Og et naturligt udgangspunkt herfor er, når vi taler om Sønderjylland, Genforeningen i 1920.

De sønderjyske pengeinstitutters historie rækker selvfølgelig meget længere tilbage - også til tiden forud for 1864. Men Sønderjyllands pengeinstituthistorie i det 20 . århundrede er i sagens natur anderledes end resten af landets, idet Genforeningen også på finansområdet stillede landsdelen over for særlige omstillingskrav - økonomisk, organisatorisk og administrativt. Men det indebar også nye forretningsmæssige muligheder for banker og sparekasser med aktivitet $i$ landsdelen. Omvæltningerne og det umiddelbare udkomme heraf er indgående 
belyst i Chr. Hübbes artikel "De sønderjydske Pengeinstitutter efter Genforeningen « i 1931-udgaven af "Sønderjyske Årbøger«.

Hübbes artikel er skrevet kun godt 10 år efter Genforeningen, men "afleverer« ikke desto mindre et sønderjysk pengeinstitutlandskab, som i grove træk holdt sig frem til 1960'erne. Den omfattende genforeningstilpasning var mere eller mindre overstået. Sønderjylland var $\mathbf{i}$ 1930 vel dækket med pengeinstitutter: 40 selvstændige sparekasser og 14 banker og en halv snes andelskasser. Hertil filialer af de københavnske hovedbanker Landmandsbanken og - først og fremmest Kjøbenhavns Handelsbank. Sidstnævnte var landsdelens største bank og havde afdelinger i de seks største byer samt et betydeligt antal underliggende agenturer i mindre bysamfund ${ }^{4}$. I alt var der ca. 180 bank- og sparekasseafdelinger i Sønderjylland.

Målt på antal selvstændige og repræsenterede pengeinstitutter såvel som på antal betjeningssteder i landsdelen i forhold til hele landet var Sønderjyllands andel i 1930 7-8 pct., og helt frem til i dag har disse procentandele holdt sig godt over 5 . Sønderjyllands befolkningstal udgør i underkanten af 5 pct. af Danmarks. Målt med den alen er sønderjyderne således - og har i mange år været - relativt godt forsynet med pengeinstitutter.

De fleste sønderjyske institutter var oprindelig, og forblev længe, ganske små og meget lokale. Mange sparekasser og nogle af bankerne havde således deres virke via en enkelt afdeling inden for ét sogns grænser. Åbningstiderne kunne være begrænset til et par timer lørdag eftermiddag. Betjeningen i mange agenturer - og selv i en del »hovedkontorer« - har næppe omfattet levering af pengeinstitutydelser ud over det allermest nødtørftige: ind- og udbetalinger med sparekasseeller bankbogen som omdrejningspunktet. Men en god håndfuld større banker og sparekasser med hjemsted og aktivitet $\mathrm{i}$ og $\mathrm{i}$ omegnen af regionens store byer skilte sig ud, hver især med op til en halv snes filialkontorer og agenturer. $\mathrm{Og}$ i de største bankafdelinger kunne man få hele paletten - det være sig ind- og udlån, realkreditformidling, vekselhåndtering og "udlejning af boxer«. Sparekassernes tilbud til kunderne var, også i de større afdelinger, begrænset af et lovbestemt forbud mod at drive »bankvirksomhed «, bl.a. vekseldiskontering, garantistillelse og valutahandel ${ }^{5}$.

Det pengeinstitutbillede holdt sig rimelig stabilt gennem 1930'ernes økonomiske krise og en, ikke mindst i Sønderjylland, barsk og politisk vanskelig periode op til og igennem 2 . verdenskrig. 
Figur 2: Pengeinstitutlokaliteter i Sønderjylland sidst i 1960'erne

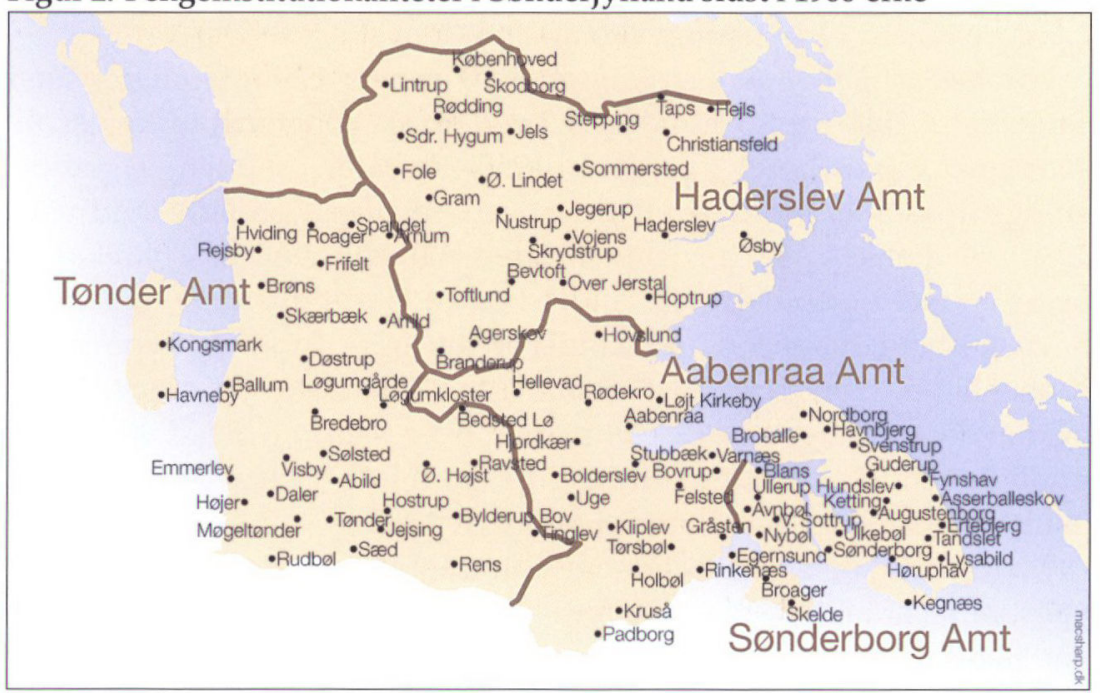

Kortet viser de byer/lokaliteter i Sønderiylland, hwor der i slutningen af 1960'erne var bemandede pengeinstitut-betjeningssteder. De daværende i alt 52 pengeinstitutter havde tilsammen 221 betjeningssteder spredt på de viste byer i landsdelen. Flest $i$ det tyndt befolkede Tonder amt, som også var karakteriseret ved flest (små) selvstændige sparekasser, jf. også figur 1 foran.

Efter 1930 er der ikke oprettet nye sparekasser i Sønderjylland, mens der til gengæld blev ned- eller sammenlagt fire sparekasser i 30 'erne, to i 40'erne, en enkelt i 50'erne og yderligere fire frem til 1968, hvor der således endnu var 29 selvstændige sønderjyske sparekasser 6 . Udviklingen i den sønderjyske sparekassesektor frem til 1970 er udførligt beskrevet i G. Japsens »De nordslesvigske sparekassers historie«, udgivet af Historisk Samfund for Sønderjylland i 1970.

De sønderjyske bankers udvikling ses ikke at have fået en tilsvarende systematisk beskrivelse og belysning siden Hübbes føromtalte 1931-artikel. Strukturelt er perioden frem til slutningen af 1960'erne dog også relativt fredsommelig - sammenlignet med, hvad der derefter skete. Dog forsvinder tre ud af 14 selvstændige banker?

Fremme ved 1968 var det stadig de lokale købstadsbanker og -sparekasser, der dominerede det sønderjyske pengeinstitutbillede. To af hovedbankerne havde dog også konsolideret deres tilstedeværelse i Sønderjylland. Først og fremmest Kjøbenhavns Handelsbank, som i 1968 målt på sine 30 afdelinger - fortsat - var landsdelens største 
pengeinstitut. Sideløbende var Andelsbanken blevet en bredt funderet aktør med i alt 16 sønderjyske afdelinger, jf. også skema 1.

Sønderjylland var godt dækket med pengeinstitutter i 1968: Flere end 50 institutter med over 200 bemandede betjeningssteder fordelt på flere end 100 sønderjyske byer og landsbyer.

\section{Forandringsmiljøet i 1960'erne}

I løbet af 1960'erne slog omstillingen af Danmark fra sogne-/småbrugssamfund til by-/industriland for alvor igennem. De små enheder, der tidligere havde domineret væsentlige erhvervssektorer inden for både håndværk, industri, handel og landbrug, gik sammen, blev opkøbt eller udviklede sig simpelthen, bl.a. via øget mekanisering, til større virksomheder - fabrikker, forretninger og gårde. Sideløbende med industrialiseringen fortsatte urbaniseringen af det danske samfund.

Folkevandringen fra land til by var en logisk følge af væksten i byerhvervene og det hertil hørende behov for arbejdskraft og den samtidige omlægning og modernisering af landbrugserhvervets tidligere så arbejdskraftintensive driftsformer. Medvirkende til det kraftige økonomiske opsving, der drev samfundsomstillingen i 1960'erne, var i høj grad den åbning og liberalisering af samhandelen, som i disse år var det internationale mantra.

Disse udviklingstendenser påvirkede og ændrede $\mathrm{i}$ sagens natur såvel virksomheders som borgeres efterspørgsel efter varer og tjenester. Også når det drejede sig om pengeinstitutydelser. Forskellene i pengeinstitutternes forudsætninger for at løse kundernes behov blev hurtigt åbenbare. De i 1960 mange - tæt ved 650 - danske banker og sparekasser var generelt for små, kapital- og mandskabsmæssigt, og besad slet ikke den fornødne faglige og tekniske kompetence til at løfte de opgaver, som voksende og i stigende grad internationalt orienterede erhvervsforetagender efterspurgte. Yderligere forholdt det sig som nævnt således, at sparekasserne i henhold til lovgivningen ikke måtte levere væsentlige pengeinstitutydelser - bl.a. hverken garantistillelse eller valutahandel - til erhvervslivet. Hertil kom, at bankerne i løbet af 1960'erne i højere grad end tidligere rettede interessen mod det almindelige privatkundesegment, som hidtil havde været sparekassernes gebét. Baggrunden var den velstandsstigning, der fulgte med industrialisering og urbanisering med øgede behov for 
finansiering af privatkundernes anskaffelse af større aktiver - det være sig parcelhus, bil eller andre varige forbrugsgoder - og for servicering af det hastigt voksende lønmodtagersegment med lønkontoog budgetprodukter. På det hidtil ellers så stilfærdige, aftaleregulerede og kontrollerede pengeinstitutmarked spirede dermed en reel konkurrence om kunderne.

Det var i 1960'erne bredt opfattelsen - også i finanssektorens egne rækker - at strukturen, for at imødekomme de ændrede behov og krav, skulle tilpasses. Der var kort og godt for mange og for små pengeinstitutter. Den betydeligste hindring for strukturrationaliseringer - skrappe skatteregler for aktionærer i forbindelse med fusioner blev lempet i 1964. Hermed var vejen banet for flere bankfusioner. På sparekassesiden skulle der gå yderligere 10 år, før en ny bank- og sparekasselov ligestillede de to instituttyper rent aktivitetsmæssigt. ${ }^{8}$

Uanset formelle hindringer gik der imidlertid i årtiets løb hul på bylden. Fra 1960 til 1968 faldt antallet af selvstændige sparekasser på landsplan med næsten 100 til knap 400 og antallet af selvstændige banker med ca. 50 til rundt 110. Disse ændringer skete i vid udstrækning ved, at små og mellemstore lokale institutter gik sammen til større egnssparekasser og -banker ${ }^{9}$. I mindre omfang var der tale om, at store banker eller sparekasser overtog små. Denne alternative form for konsolidering er mere typisk for perioden 1968-75, hvor pengeinstitutlandskabet for alvor tegnes om. Inden for dette korte spand af år halveres antallet af selvstændige sparekasser yderligere til knap 200, og antal banker falder med 35 til 75 .

\section{Omvæltningerne i Sønderjylland omkring 1970}

Strukturforandringerne i Sønderjylland blev først til noget fra 1968 men havde da været på tegnebrættet gennem nogen tid. En sønderjysk egnsbankfusion havde således været på tale siden midten af 1950'erne - men sparekasserne kom først.

\section{Sparekasserne}

Det startede med sammenslutningen af de to store købstadssparekasser Sparekassen for Aabenraa By og Amt og Sønderborg Bys Sparekasse til Sparekassen Sønderjylland i foråret 1968. Hermed var den nationale konsoliderings- og fusionsbølge nået til Sønderjylland og landsdelens første egnsinstitut skabt. Senere samme år blev sparekas- 
sen i Ketting en del af Sparekassen Sønderjylland. Og i årene 197074 kom yderligere syv lokal- og sognesparekasser med. Det var sparekasserne i Tønder (i 1970), i Brøns, Møgeltønder og Tandslet/det sydlige Als (alle i 1971), i Hostrup (i 1972) samt endelig sparekasserne i Nordborg og Tinglev (begge i 1974), jf. også bilagstabel 1.

10 sønderjyske sparekasser var blevet til én. Men ser man på det sønderjyske landkort, udmærker Sparekassen Sønderjylland sig bl.a. ved ikke at have Haderslev Amt og Midtlandet med. Og sideløbende med dannelsen af Sparekassen Sønderjylland foregik der meget andet af betydning for pengeinstitutstrukturen i landsdelen.

Japsen (1970 s. 332) runder sin 150 års historieskrivning om de nordslesvigske sparekasser af med at notere, at »det karakteristiske har [... ] været, at landsdelens egne kræfter har været de bestemmende«. Det synspunkt var nok holdbart i 1970 og afspejlede naturligt, hvad der $\mathrm{i}$ årene umiddelbart forud var sket på det sønderjyske marked. Men man stod i 1970 endnu kun ved begyndelsen af omstillingsprocessen. I løbet af de følgende blot fem år skulle yderligere 16 sønderjyske sparekasser forsvinde i konsolideringsbølgen. Og efter 1970 peger udviklingen ikke længere overbevisende $\mathrm{i}$ en retning, hvor "landsdelens egne kræfter er bestemmende«. De nævnte 10 by- og lokalsparekasser endte nok med at blive samlet $\mathrm{i}$ landsdelsinstituttet Sparekassen Sønderjylland med bred dækning i hele det sydlige Sønderjylland. Men 13 andre sønderjyske sparekasser - mange af dem med hjemsted i det nordlige Sønderjylland - indgik sideløbende hermed i større institutter med adresse uden for landsdelen, længere oppe i Jylland eller i Kobenhavn.

Sparekassen Sønderjylland var som nævnt det første skud. Det næste - i 1969 - var en lille sag. Og dog. Den store, i disse år særdeles ekspansive, københavner-sparekasse Bikuben overtog i det år Spare- og Laanekassen for Ulkebøl Sogn. Det var historisk. Den første sønderjyske sparekasseovertagelse "udefra " nogensinde. Japsen (1970 s. 332) omtaler Bikubens indtog i Ulkebøl som "en tendens, der ellers ikke har sat sig præg på sparekassernes seneste udvikling i Sønderjylland «. Men det skulle vise sig at være et signal om, at den konsolidering, som året forinden var startet $\mathrm{i}$ landsdelen, ikke ville få lov at blive et internt sønderjysk anliggende. Offensive landsinstitutter måtte forventes at komme på banen. Og netop $\mathrm{i}$ disse år var Bikuben om nogen aggressiv som udgangspunkt på Sjælland, men fra 1968 også i hovedlandet - først nord for og nu også syd for Kongeåen. Og i 1972 fulgte Bikuben op med 
overtagelse af Skodborg og Omegns Spare- og Laanekasse og i 1974 af Skærbæk Sparekasse, som så sent som i 1972 var dannet ved en sammenlægning af Spare- og Laanekassen for Skærbæk og Omegn og Spare- og Laanekassen for Døstrup Sogn. Bikubens sønderjyske tilstedeværelse styrkedes yderligere ved overtagelsen 1973 af den nødlidende J.A.K. Bank, herunder dennes i 1969 etablerede afdeling i Aabenraa samt afdelinger i Over Jerstal og Skærbæk ${ }^{10}$.

I 1970 virkeliggjorde tre Haderslev-sparekasser en efterhånden nogle år gammel plan om at gå sammen til én: Sparekassen Haderslev. Et oplagt match for Sparekassen Sønderjylland skulle man mene. Men alligevel ikke. Den nye Haderslev-sparekasse overtog i 1971 to lokalsparekasser i den vestlige del af det gamle Haderslev Amt - Agerskov Sparekasse og Toftlund og Omegns Sparekasse. Nu var den, set udefra, i endnu højere grad den rette makker for Sparekassen Sønderjylland, som jo på sin side var i fuldt sving med at samle lokalsparekasserne med udgangspunkt i Als, og i det sydlige og det vestligste Sønderjylland - i de gamle Sønderborg, Aabenraa og Tønder Amter.

Men sådan gik det ikke. Haderslev-sparekassen valgte i 1972 at gå nordpå og ind i sammenslutningen Sparekassen Sydjylland, som med hjemsted i Vejle yderligere blev strikket sammen af sparekasser i Fredericia, Varde, Vejen og Ribe. Sydjyllands-projektet har organisatorisk og ledelsesmæssigt formentlig forekommet mere perspektivrigt end Sønderjyllands-løsningen, hvorfor man i Haderslev foretrak at blive 6. hjul på et sydjysk køretøj snarere end 3. hjul på et sønderjysk.

Sparekassen Sydjylland supplerede i øvrigt sin tilstedeværelse i det nordlige Sønderjylland ved overtagelse af Sparekassen for Christiansfeld og Omegn i 1975 - og var i 1976 millimeter fra også at overtage Sparekassen Løgumkloster ${ }^{11}$.

Der var dog også et par rent lokale fusioner mellem mindre sparekasser i perioden. Visby Sogns Sparekasse og Bredebro-Ballum Sparekasse gik således i 1971 sammen under navnet Sparekassen Bredebro, og Sparekassen Højer blev i 1973 dannet ved en sammenlægning af Sparekassen for Højer og Omegn, Daler Sogns Sparekasse og Emmerlev Sogns Spare- og Laanekasse.

\section{Bankerne}

I 1970 kom også bankerne med i spillet. Mest bemærkelsesværdigt var, at den store bank i det hidtidige Haderslev Amt, Haderslev Bank med ni afdelinger i nordøst- og midt-Sønderjylland, valgte at lade sig 
Figur 3: Samarbejdende sonderjyske banker i 1960'erne

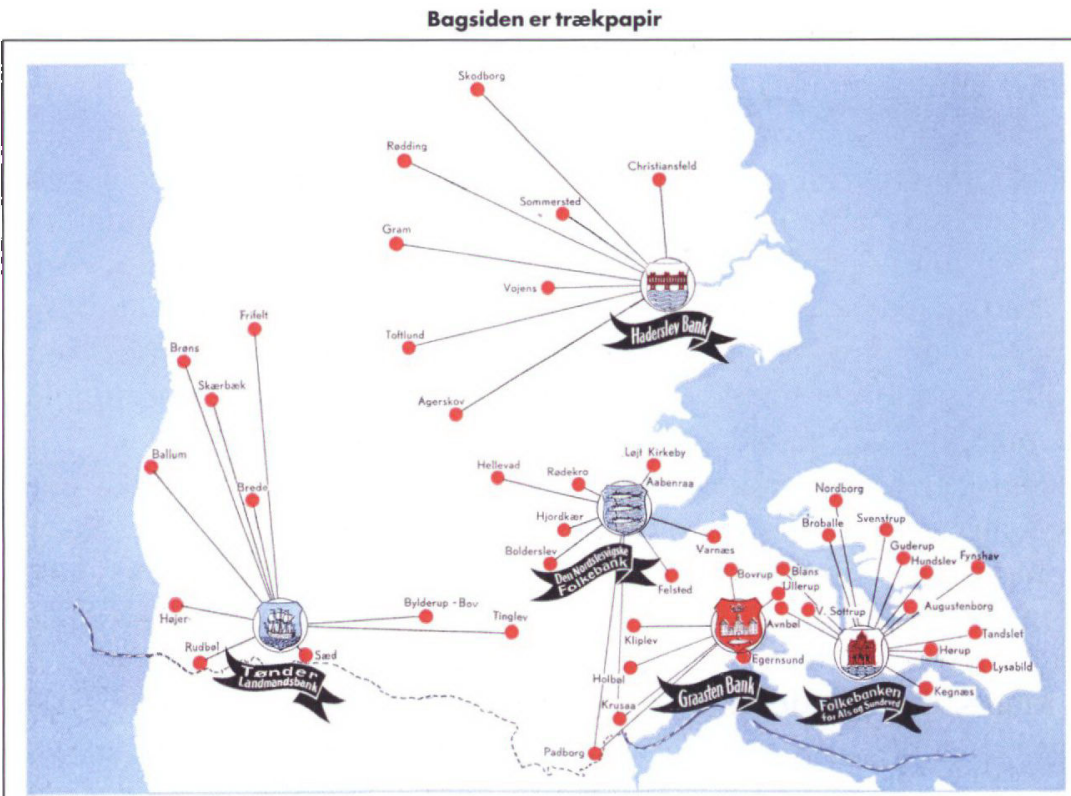

Vore ovennæunte banker er hjemstavnens egne

De er oprettede af dens befolkning og igennem àrene udbyggede i nøje kontakt med landsdelens historiske fortid og erhvervsmæssige udvikling.

Dette intime tilhørsforhold til egn og befolkning gor, at vore banker, i dag som for, er naturlige grosteder for de lokale penge og formidlere af disses omsætning.

Vore bankers nære samarbejde gor det muligt for os at løse betydelige opgaver og give vore kunder 5 hjemlige og erfarne bankforbindelser for een.

\section{TØNDER LANDMANDSBANK $/ / 5$}

Sådan markedsforte de fem store sønderiyske banker sig $i$ fallesskab $i$ slutningen af 1960'erne - med sammenlagt 57 afdelinger $i$ landsdelen. Den landsdelsdækkende Sanderjyllands-bank tegner sig tydeligt. Bemærk, at bagsiden pd denne markedsforingsgenstand var et trakpapir. 30 ar senere ville det have varet en musemåtte.

overtage af Privatbanken, som hidtil slet ikke havde været repræsenteret i landsdelen. Privatbanken erhvervede samme år også Gram Bank, og var med disse »to slag « blevet en ny markant hovedbank og aktør på det sønderjyske marked.

Haderslev Banks valg af Privatbanken som partner var en alvorlig streg $\mathrm{i}$ regningen for de folk, der i mere end et tiår havde arbejdet med planen om én stor sønderjysk regionalbank - omfattende alle Sønderjyllands fem, i forvejen på en række områder samarbejdende, store bybanker med hjemsteder i Aabenraa, Sønderborg, Gråsten, 
Tønder og Haderslev og således dækkende praktisk talt hele landsdelen. Uenighed om aktieombytningsforholdet var imidlertid udslagsgivende for, at Haderslev Bank gik til Privatbanken, og at kun de fire andre fandt sammen. De fik til gengæld travlt med at få virkeliggjort det sønderjyske regionalbank-projekt. Midt på året 1970 kunne Sydbank præsenteres som en sammenlægning af Gråsten Bank, Tønder Landsmandsbank, Folkebanken for Als og Sundeved fra Sønderborg og Den nordslesvigske Folkebank fra Aabenraa. Én sønderjysk regionalbank med 50 afdelinger skulle nok kunne levere bankvarerne til stadigt mere krævende og sofistikerede kunder, også på erhvervsområdet, og dermed hamle op med den tiltagende konkurrence udefra. At projektet var bæredygtigt, har historien dokumenteret.

Men ser man på landkortet, var den regionale sønderjyske bank Sydbank altså - ligesom tilfældet var med den regionale sønderjyske sparekasse - karakteriseret ved ikke at have det gamle Haderslev Amt, herunder også Midtlandet, med. Sydbank er i dag en stor lokal bank mange steder i landet, eksempelvis i Vejle, Esbjerg, Odense og Slagelse. Alle steder, hvor der siden hen er overtaget banker. Det samme kan ikke siges om Sydbank i Haderslev-området. Banken etablerede ganske vist i 1973/74 egne nye afdelinger i Haderslev og Vojens. Men bankens position på den del af den naturlige sønderjyske hjemmebane, der udgøres af det gamle Haderslev Amt, er aldrig blevet den samme som $i$ resten af landsdelen.

I 1970 forsvandt yderligere to lokale sønderjyske banker. Den Danske Landmandsbank overtog Banken for Jels og Omegn og Skærbæk Bank.

Helt fremme ved årsskiftet 1969/70 var der endnu 11 sønderjyske banker tilbage. Men med Sydbank-fusionen og 3 hovedbankovertagelser var forandringstempoet i løbet af 1970 godt og vel kommet på omgangshøjde med resten af landet, hvor antallet af selvstændige banker i løbet af 1960'erne næsten blev halveret.

\section{Status anno 1975}

Når boet således gøres op - anno 1975 - var 33 ud af 40 lokale sønderjyske bank- og sparekassenavne forsvundet fra landkortet siden 1968 - på kun syv år. 19 af dem indgik i sønderjyske fusioner, heraf 10 i Sparekassen Sønderjylland og fire i Sydbank. De øvrige 14 blev opslugt af pengeinstitutter med hjemsted uden for landsdelen - 10 sparekasser af Sparekassen Sydjylland og Bikuben og fire banker af de københavnske hovedbanker Landmandsbanken og Privatbanken. 
Iøjnefaldende er det, at det gamle Haderslev Amt stort set blev lænset for selvstændige pengeinstitutter, og at ingen af Haderslev-institutterne gik ind $\mathrm{i}$ de sønderjyske sammenslutninger.

Ud over de 40 lokale var der i 1968 repræsenteret en sparekasse og seks banker med hjemsted uden for Sønderjylland. Heraf var tre københavnske hovedbanker. De havde i 1968 i alt godt 60 afdelinger i Sønderjylland. Midt i 1970'erne var antallet af "fremmede « institutter næsten fordoblet til 12, dels som følge af de foran nævnte overtagelser af lokale banker og sparekasser, dels af andre større lands- og landsdelsdækkende institutters ekspansion og hermed følgende »invasion« og filialnyetablering i Sønderjylland.

Alt i alt blev pengeinstitutbilledet i Sønderjylland voldsomt forrykket på ganske få år. Der var langt færre lokale banker og sparekasser og $\mathrm{i}$ det hele taget færre forskellige institutter at vælge imellem. Men sønderjydernes adgang til en nærliggende bank- eller sparekassefilial har aldrig været bedre end i anden halvdel af 1970'erne. Da bølgerne havde lagt sig i 1975 var der 238 sønderjyske betjeningssteder - mod 216 i 1968, jf. skema 1. Og kontorerne var fortsat spredt på næsten 100 byer i landsdelen. Det skal dog bemærkes, at nogle af de nye betjeningssteder var de for den periode meget udbredte holdepladser for bank- og sparebusser («bus-filialer «) ${ }^{12}$. Og mens der - meget forsigtigt - blev lukket enkelte kontorer i de mindre landsbysamfund, åbnedes der sideløbende flere nye filialer typisk i de centre, der skød op i forbindelse med fremkomsten af nye parcelhus- og boligkvarterer i de større bysamfund.

Helhedsbilledet indikerer, at strukturforandringerne omkring 1970 for de mindste institutters vedkommende var drevet af praktisk teknisk, faglig, organisatorisk og ledelsesmæssig - nødvendighed. For de større drejede det sig i høj grad om markedstilstedeværelse og positionering. Kun undtagelsesvist var der tale om institutter i økonomisk nød, og målsætningen var bestemt ikke filialrationalisering $i$ hvert fald ikke umiddelbart.

Der var i 1975 syv sparekasser og fire banker tilbage med hjemsted i landsdelen. Det var Sparekassen Sønderjylland og seks lokale sparekasser i Rødding (Frøs), Broager, Løgumkloster, Ravsted, Bredebro og Højer. Endvidere Sydbank og tre lokale banker med rødder i det tyske mindretal: Aabenraa Kreditbank, Tønder og Omegns Bank og Haderslev Creditbank.

Men samtidig var som nævnt repræsentationen »udefra«, primært 
Skema 1: Sparekasser og banker i Sonderjylland 1968-75

\begin{tabular}{|c|c|c|c|}
\hline 1968 & Afd. & 1975 & Afd. \\
\hline 29 sonderjyske sparekasser & 77 & 7 sonderjyske sparekasser & 48 \\
\hline $\begin{array}{l}\text { Aabenraa by og amt (8), Sonderborg } \\
\text { by (12), Ketting (1), Tonder (2), Brons } \\
\text { (1), Maggeltonder (1), Sydlige Als / } \\
\text { Tandslet (1), Hostrup (1), Nordborg } \\
\text { (2), Tinglev (3) }\end{array}$ & 32 & Sonderjylland & 28 \\
\hline Frns & 5 & Frns & 5 \\
\hline Broager & 3 & Broager & 4 \\
\hline Visby (1), Bredebro-Ballum (3) & 4 & Bredebro & 4 \\
\hline Logumkloster & 3 & Logumkloster & 4 \\
\hline Ravsted & 1 & Ravsted & 1 \\
\hline Hajer (1), Daler (1), Emmerlev (1) & 3 & Hajer & 2 \\
\hline $\begin{array}{l}\text { Haderslev By (1), Haderslev Omegn } \\
\text { (4), Haderslev Amt (9), Agerskov } \\
\text { (1), Toftlund (3), Christiansfeld (2) }\end{array}$ & 20 & (Del af Sparekassen Sydjylland) & \\
\hline $\begin{array}{l}\text { Ulkebøl (1), Skodborg (2), Skærbak } \\
\text { (2), Døstrup (1) }\end{array}$ & 6 & (Del af Bikuben) & \\
\hline 11 senderjyske banker & 77 & 4 senderjyske banker & 66 \\
\hline $\begin{array}{l}\text { Den Nordslesvigske Folkebank (13), } \\
\text { Grásten Bank (11), Folkebanken for } \\
\text { Als og Sundeved (13), Tonder Land- } \\
\text { mandsbank (11) }\end{array}$ & 48 & Sydbank & 56 \\
\hline Aabenraa Kreditbank & 5 & Aabenraa Kreditbank & 5 \\
\hline Tønder og Omegns Bank & 4 & Tønder og Omegns Bank & 4 \\
\hline Haderslev Creditbank & 1 & Haderslev Credithank & 1 \\
\hline Jels (2), Skarbak (4) & 6 & (Del af Landmandsbanken) & \\
\hline Haderslev Bank (9), Gram (4) & 13 & (Del af Privatbanken) & \\
\hline 1 ikke-senderjysk sparekasse & 2 & 2 ikke-sonderjyske sparekasser & 40 \\
\hline \multirow[t]{3}{*}{ Sdr. Bjært og Vejstrup } & 2 & (Del af Bikuben) & \\
\hline & & Bikuben & 14 \\
\hline & & \begin{tabular}{|l|} 
Sparekassen Sydjylland \\
\end{tabular} & 26 \\
\hline 6 ikke-sonderjyske banker & 60 & 10 ikke-sonderjyske banker & 84 \\
\hline Kjabenhavns Handelsbank & 30 & Kjøbenhavns Handelsbank & 34 \\
\hline Andelsbanken & 16 & Andelsbanken & 17 \\
\hline Den Danske Landmandshank & 6 & Den Danske Landmandsbank & 10 \\
\hline Sydjydsk Landmandsbank, Ribe & 5 & Den Danske Provinsbank & 5 \\
\hline Banken for Vejen og Omegn & 1 & Banken for Vejen og Omegn & 1 \\
\hline \multirow[t]{6}{*}{ J.A.K. Bank } & 2 & (Del af Bikuben) & \\
\hline & & Privatbanken & 12 \\
\hline & & Aktivbanken & 1 \\
\hline & & Arbejdernes Landsbank & 1 \\
\hline & & Finansbanken & 2 \\
\hline & & Fxllesbanken & 1 \\
\hline Totalt 47 banker og sparekasser & 216 & Totalt 23 banker og sparekasser & 238 \\
\hline
\end{tabular}

Tallene i parentes ved de oprindelige institutter i 1968 angiver de pảgældende bankers og sparekassers daværende filialantal. Ud over de anfurte institutter var andelskasserne Asserballeskov, Tinglev, Sundeved, Tandslet og Rørna i 1968 repræsenteret med hver en afdeling. I 1975 havde de nævinte andelskasser sammenlagt seks afdelinger, hvortil kom J.A.K. Andelskassens afdeling i Rødding. 
via overtagelserne, øget markant. Nye sparekasser i forhold til 1968 var Sydjylland, som i 1975 havde 26 sønderjyske afdelinger, og Bikuben med ti. Begge havde undervejs suppleret med egne nyetableringer. Privatbanken var med afsæt i de overtagne Haderslev- og Grambanker veletableret i det nordlige Sønderjylland med i alt 12 afdelinger. Den Danske Landmandsbank var med overtagelserne i Jels og Skærbæk oppe på ti afdelinger. Yderligere var Arbejdernes Landsbank og Fællesbanken for Danmarks Sparekasser kommet til, hver med en afdeling i Haderslev, Aktivbanken var startet i Padborg, og Finansbanken i Aabenraa og Kruså. Kjøbenhavns Handelsbank og Andelsbanken, der begge i forvejen var stærkt repræsenteret i landsdelen, deltog ikke i den sønderjyske konsolidering omkring 1970. Men de to københavnske hovedbanker fastholdt deres markedsposition. Kjøbenhavns Handelsbank var med flere end 30 afdelinger fortsat den klart største ikke-sønderjyske bank, mens Andelsbanken havde 17 afdelinger.

For fuldstændighedens skyld skal det nævnes, at Sydjydsk Landmandsbank med hjemsted i Ribe ligesom Banken for Vejen og Omegn havde afdelinger i Sønderjyllands nord- og vestlige grænseegne. Begge banker blev overtaget af Den Danske Provinsbank - $i$ henholdsvis 1970 og 1980. Endvidere var Sdr. Bjært og Vejstrup Sognes Sparekasse repræsenteret med et par afdelinger i landsdelens nordøstlige hjørne. Sparekassen blev i 1971 overtaget af Kolding Sparekasse, som i 1974 indgik i Bikuben ${ }^{13}$.

\section{Perioden frem til 1990}

De sidste år af 1970'erne og de første af 1980'erne var strukturelt meget stilfærdige $\mathrm{i}$ den danske pengeinstitutsektor. En stor tilpasnings- og fusionsbølge var gennemført. Nu skulle de nye, større organisationer ind- og samkøres, og sparekasserne skulle sideløbende hermed indrette sig på de nye forretningsmæssige muligheder, som lovændringerne fra 1974 åbnede op for. Når det generelt gik "godt " for langt de fleste, også "nye«, institutter, skal det ses i sammenhæng med, at konkurrencen i sektoren reelt set var sat ud af kraft i denne periode. Det var i de år, hvor dansk økonomi bevægede sig hen imod og på »afgrundens rand « - en situation og udvikling, som indebar, at der blev ført en ekstremt stram penge- og kreditpolitik, bl.a. med 
snævre rammer for udlånsgivningen. Det virkede klart konserverende for pengeinstitutstrukturen ${ }^{14}$.

Det så helt anderledes $\mathrm{ud}$, da man kom ind i første halvdel af 1980 'erne. $\mathrm{Nu}$ handlede det om modernisering, liberalisering og internationalisering af den danske finanssektor - forandringsfaktorer, der for alvor blev omsat i strukturtilpasninger i forbindelse med de store pengeinstitutfusioner omkring 1990. Men helt frem til da forrykkedes helhedsbilledet af pengeinstitutlandskabet kun lidt.

Af de 11 selvstændige sønderjyske pengeinstitutter, som kom ud af tumulterne omkring 1970, faldt kun et fra frem til 1990. Det var Haderslev Creditbank, der ligesom Kreditbanken i Aabenraa, Tønder og Omegns Bank samt Løgumkloster Sparekasse havde rødder i og nære relationer til det tyske mindretal i Sønderjylland. Creditbanken blev i 1985 overtaget af Den Danske Bank, hvilket styrkede Den Danske Banks relativt svage lokalposition i Haderslev. Det må i den forbindelse noteres som - måske - bemærkelsesværdigt, at der ikke blev tale om en sammenlægning af Creditbanken i Haderslev med den i øvrigt ligeartede og -sindede Kreditbank i Aabenraa. Endnu en gang valgte man i Haderslev det lokale sønderjyske/nordslesvigske fra og fandt en partner uden for landsdelen/nordpå.

Man kan gætte på, at også Sydbank, der som nævnt ganske vist allerede i 1973 havde etableret sig i Haderslev på egen hånd, og som i løbet af 80'erne i stigende grad fokuserede på ekspansion uden for Sønderjylland, kunne have været interesseret $i$ at styrke fodfæstet $i$ Haderslev via Creditbanken. Men man har næppe fået buddet.

Sydbank, der siden starten i 1970 havde markedsført sig som "Den sønderjyske bank «, var sidst i 70'erne gået over Kongeåen og havde etableret sig i Fredericia og Kolding - og i 1981 åbnede banken afdeling i hjertet af København, på Kgs. Nytorv. Og herefter gik det stærkt. I 1982 overtog Sydbank den lokale Århus Bank, og i 1983 den Svendborg-baserede Fynske Bank. Det var omkring det tidspunkt, hvor sloganet "Den sønderjyske bank« blev skiftet ud med "Den levende bank « ${ }^{15}$.

Året efter - i 1984 - åbnede Sydbank som den første danske bank en afdeling syd for den dansk-tyske landegrænse. Der var med filialen i Flensborg tale om et historisk initiativ, som et par år efter blev fulgt op af en Hamborg-filial og i 2007 af en afdeling i Kiel. Bortset fra omdannelsen i 1927 af en dansk Flensborg-sparekasse til danskhedens bank i Sydslesvig, Union-Bank, var der ikke siden Genfor- 
eningen etableret danske banker syd for grænsen ${ }^{16}$. Den store lokalt funderede bank i Nordslesvig, Sydbank, drev nu også bank i Sydslesvig. Alt tyder på, at denne beslutning om ekspansion også mod syd har været rigtig for Sydbank - både forretnings- og profilmæssigt.

Sydbank videreførte i resten af 80'erne landvindinger uden for Sønderjylland. Egne etableringer i Vejle, Randers og Aalborg blev suppleret af to københavnske overtagelser - 6' juli Banken i 1987 og Fællesbankens hovedstadsfilialer i 1988. Ved årtiets afslutning var Sydbank meget andet og meget mere end en sønderjysk regionalbank. Stadig lokalt forankret, men samtidig nationalt - og tilmed grænseoverskridende - ekspanderende.

Både relativt og absolut var der »mindre Sønderjylland « i Sydbank i slutningen af $80^{\prime}$ erne end midt i 70'erne. Sideløbende med udvidelserne i resten af landet blev der skåret godt ned på hjemmebanen. Sydbank havde i 197556 filialer - alle beliggende i Sønderjylland. I 1988 var bankens filialantal på landsplan 75 filialer, hvoraf »kun« halvdelen - 39 - lå i Sønderjylland. Der var kommet gang i den sønderjyske rationalisering.

I en vis forstand minder Sparekassen Sønderjyllands historie frem til udgangen af 1980 'erne om Sydbanks. Der var - med stigende intensitet efterhånden som årene gik - konkurrence om succespositionen i landsdelen. Men sparekassen var og forblev »lillebror « - med en kapital- og forretningsbase, der udgjorde mellem en fjerde- og en tredjedel af Sydbanks. Konkurrencen de to sønderjyske regionalinstitutter imellem i 80'erne var i øvrigt typisk for de mellemstore/regionale banker og sparekasser landet over. 70'ernes aftale- og karteltankegang var en saga blot, og alt andet lige var der mere for kunderne at komme efter $\mathbf{i}$ pengeinstitutterne. Så meget mere, at de forste år $i$ $90^{\prime}$ erne blev endog meget problematiske for de mest offensive i flokken. For nogle fatale.

Sparekassen Sønderjylland-sammenslutningen var fra starten, ligesom Sydbanks i 70'erne, forsigtig og omstændelig, og sparekassen var i sit virke frem til begyndelsen af 80 'erne ikke just banebrydende. Med ny ledelse først i 80 'erne introducerede sparekassen imidlertid en moderniseret offensiv strategi. I 1988 var den repræsenteret med 29 afdelinger i Sønderjylland og fire uden for landsdelen - i København, Århus, Horsens og Herning. Man flyttede ind i et nybygget hovedsæde i Aabenraa. Samtidig tog Sparekassen Sønderjylland de nye ejerskabs- og kapitalmuligheder $i$ anvendelse og blev et af landets 
første sparekasse-aktieselskaber ${ }^{17}$. Konkurrenterne kunne bare komme an.

Det skal noteres, at Sparekassen Sønderjylland frem til slutningen af 80 'erne stort set videreførte sin oprindelige filialtilstedeværelse i den hjemlige landsdel. Der blev lukket nogle få og åbnet enkelte andre. Hensynet til de mange mindre fusionsdeltagere har nok vejet tungt. Så antallet af sønderjyske afdelinger var uæendret. Modsat Sydbank forsøgte sparekassen ikke ved egne nyetableringer at lukke hullet nordpå i det gamle Haderslev Amt.

I perioden op til 1990 reduceredes antallet af aktører med hjemsted uden for landsdelen fra 12 til ti. Baggrunden var, at Vejen og Omegns Bank i 1980 blev overtaget af Provinsbanken, som i årtiets løb lukkede de sønderjyske afdelinger, og at Finansbanken i 1980 blev overtaget af Jyske Bank. Endvidere blev Fællesbanken i 1984 udskiftet med SDS, som også kom til Sønderborg.

Filialantallet, der toppede omkring 235 i anden halvdel af 70'erne, var sidst i 80'erne faldet med næsten $20 \%$ til knap 190. Det bemærkes, at der i filialantallet for 1975 indgår en snes bus-filialsteder, der for de flestes tilfælde igen var afviklet i 1988. Forrest mht. strukturrationalisering i perioden gik - naturligt nok - en række af de afdelingsmæssigt store institutter: Sydbank (med 17), Sparekassen Sydjylland (med ti), og Kjøbenhavns Handelsbank (med 12), jf. skema 2.

\section{Omvæltningerne omkring 1990}

Strukturtilpasningen var ikke gået helt i stå efter det første voldsomme ryk omkring 1970. Men der var som nævnt langt færre fusioner i sidste halvdel af 70'erne og i 80'erne, og der var ikke tale om en bølge. Ikke desto mindre faldt antallet af selvstændige danske sparekasser i perioden med 70 - til ca. 130, mens bankantallet, bl.a. som følge af et ikke ubetydeligt antal nyetableringer, kun var svagt vigende: fra ca. 80 til omkring 70. Af det foregående fremgår, at Sønderjylland strukturelt og pengeinstitutlandskabsmæssigt ikke oplevede store forandringer $\mathrm{i}$ årene $1975-89$.

I slutningen af 1989 på det nærmeste eksploderede den koncentrationstendens, der havde luret $\mathrm{i}$ årene forud. Det startede på landsplan med dannelsen af mega-bankerne: Den Danske Bank, der var en sammenlægning af Den ("gamle«) Danske Bank, Kjøbenhavns Handelsbank og Provinsbanken, og Unibank, der dannedes af Privatbanken, 
Andelsbanken og SDS. Seks af landets allerstørste pengeinstitutter blev hermed til to, der tilsammen havde en markedsandel på godt $60 \%$. Af de største stod alene Bikuben tilbage - som »den gule enke“.

Forudsætningerne for og motiverne bag storfusionerne var mange. Koncentration og stordrift var en klar international tendens, og for at være med, skulle de store danske banker være meget større. Det finansielle »supermarked « med bank, realkredit, pension og forsikring under et tag var også i vælten i de år. Og de banker, der eventuelt skulle indgå makkerskaber med de store uden for pengeinstitutsektoren, skulle nødvendigvis være både store og stærke. De enkelte institutters forskelligartede udvikling var også medvirkende. Kjøbenhavns Handelsbank havde således åbenlyst mistet terræn til Den Danske Bank i løbet af 80'erne, og styrkeforholdet de to største imellem blev klart dokumenteret ved fusionen. Et meget kontant formål med storfusionerne var yderligere at fremme og retfærdiggøre den filialrationalisering, som alle kunne se måtte til - ud fra helt nøgterne omkostnings- og besparelseshensyn. Man hang på mange måder stadig fast i konsekvenserne af 70'ernes ekspansionsstrategi på filialområdet - og af de mere følelsesmæssige forpligtelser i relation til opretholdelsen af et bredt filialnet, der havde været indbygget i de foregående årtiers mange overtagelser af lokale banker og sparekasser. Nye distributionsmetoder med automater, Dankort og elektroniske betalingsløsninger overflødiggjorde i stigende grad filialernes rolle som "dagligbutikker«. Sektoren var samtidig uundgåelig part $i$ et både internationalt og rent dansk økonomisk tilbageslag af dimensioner. Store tab, ikke mindst via engagementer i en overophedet ejendomsog developerbranche, lå forude. Konsolidering og sammenslutning var en måde, hvorpå man kunne finde ly for det truende uvejr. Det gjaldt også for nogle af de allerstørste. Endelig skal nævnes, at loven fra 1988, der åbnede for, at sparekasser kunne blive aktieselskaber, og således endegyldigt muliggjorde en ligestilling mellem banker og sparekasser, var fremmende for strukturændringer og sammenlægninger på tværs af traditionelle bank-/sparekasseskel ${ }^{18}$.

De første år af 90'erne blev således en af de mest dramatiske perioder $\mathrm{i}$ dansk finanshistorie. Da røgen midt $\mathrm{i}$ årtiet var ved at lægge sig, var sektoren helt forandret. Det gjaldt også i Sønderjylland.

I februar 1990 præsenteredes et sønderjysk fusions- og kulturchok: Landsdelens to store regionale pengeinstitutter, de indædte sønderjyske konkurrenter, Sydbank og Sparekassen Sønderjylland, gik sam- 
men til Sydbank Sønderjylland. Den nye konstellation blev lanceret under sloganet »Vi gror sammen«.

Den sønderjyske storfusion skulle sikre et stærkt pengeinstitut med rod i det sønderjyske, og den indebar samtidig oplagte muligheder for generelt at optimere og rationalisere en fælles organisation, herunder at få tilpasset filialnettet. Bestræbelserne herpå blev - næppe planlagt - understøttet af, at de følgende år bød på strid forretningsmæssig modvind for den nye bank, som også var ganske påvirket af en ejendomstung engagementsportefølje. Ikke desto mindre overtog Sydbank Sønderjylland i 1994 de sunde dele af den vestjyske regionalbank, Varde Bank, og basisforretningen af den Vejle-baserede Aktivbanken, og kom i 1995 ud som en fordoblet - om end stadig noget forkommen - udgave af den Sydbank, man havde kendt frem til begyndelsen af 1990 .

$\mathrm{Nu}$ hed banken igen Sydbank. Fortsat med oprindelse og basis i Sønderjylland - og med hovedsæde i Aabenraa. Men hovedvægten i bankens forretninger, der til og med 1993 klart lå i Sønderjylland, var nu spredt på større dele af landet. Kun ca. 30\% af bankens balance kunne lokaliseres til Sønderjylland. Som det blev formuleret i 25 års jubilæumsnummeret af bankens kunde- og aktionærmagasin "EKKO « i sommeren 1995: "Med lidt landsdelspatriotisme kan man sige, at Sydbank fra at være "den sønderjyske bank« er blevet »banken for Sønderjylland og omegn«".

Men ikke engang den sønderjyske storfusion på tværs af bank- og sparekasseskel i 1990 kunne reparere på det forhold, at banker og sparekasser fra det gamle Haderslev Amt tilbage omkring 1970 ikke kom med i landsdelens regionale institutter, og at området derfor stod - og stadig står - uden for Sønderjyllands pengeinstitutfællesskab.

Fremme i 1997, da den "nye "Sydbank var godt i gang med at genvinde et solidt fodfæste, havde banken 120 filialer over store dele af landet. Heraf var de 36 i Sønderjylland. Og så skal man betænke, jf. skema 2, at Sydbank og Sparekassen Sønderjylland blot ni år tidligere - tilbage i 1988 - tilsammen var repræsenteret med 68 afdelinger i den hjemlige landsdel.

Det var en sønderjysk fusion med klokkeklar effekt på filiallandskabet.

I 1988 var der repræsenteret i alt 20 banker og sparekasser i Sønderjylland. Halvdelen var »lokale« med hjemsted $i$ landsdelen. Ud over 
Skema 2: Pengeinstitutter i Sonderjylland i perioden 1975-2009.

\begin{tabular}{|c|c|c|c|c|c|}
\hline Filialer i Senderiylland af & 1975 & 1988 & 1997 & 2009 & Filialer i Sonderjylland af \\
\hline Aabenraa Kreditbank & 5 & 3 & 2 & 3 & Kreditbanken \\
\hline Tønder og Omegns Bank & 4 & 4 & 6 & 8 & Tonder Bank \\
\hline Sydbank & 56 & 39 & \multirow[t]{3}{*}{36} & \multirow[t]{3}{*}{25} & \multirow[t]{3}{*}{ Sydbank } \\
\hline Sparekassen Sonderjylland & 29 & 29 & & & \\
\hline Aktivbanken & 1 & 1 & & & \\
\hline Fros Herreds Sparekasse & 5 & 5 & 4 & 5 & Fros Herreds Sparekasse \\
\hline $\begin{array}{l}\text { Broager Spare- og } \\
\text { Laanekasse }\end{array}$ & 4 & 4 & 5 & 4 & Broager Sparekasse \\
\hline Sparekassen Bredebro & 4 & 3 & 3 & 3 & Sparekassen Bredebro \\
\hline Logumkloster Sparekasse & 4 & 4 & 3 & \multirow[t]{2}{*}{5} & \multirow[t]{2}{*}{ Den Jyske Sparekasse } \\
\hline Ravsted Sparekasse & 1 & 1 & 2 & & \\
\hline Den Danske Landmandsbank & 10 & \multirow[t]{2}{*}{8} & \multirow[t]{5}{*}{15} & \multirow[t]{8}{*}{15} & \multirow[t]{8}{*}{ Danske Bank } \\
\hline Haderslev Creditbank & 1 & & & & \\
\hline Kjøbenhavns Handelsbank & 34 & 22 & & & \\
\hline Den Danske Provinsbank & 5 & \multirow[t]{2}{*}{0} & & & \\
\hline Banken for Vejen og Omegn & 1 & & & & \\
\hline Bikuben & 14 & 10 & \multirow[t]{3}{*}{17} & & \\
\hline Sparekassen Sydjylland & 26 & 16 & & & \\
\hline Sparekassen Højer & 2 & 3 & & & \\
\hline \multicolumn{3}{|l|}{ Unibank } & \multirow[t]{5}{*}{17} & \multirow[t]{5}{*}{13} & \multirow[t]{5}{*}{ Nordea } \\
\hline Privatbanken & 12 & 12 & & & \\
\hline Andelsbanken & 17 & 13 & & & \\
\hline SDS & 0 & \multirow[t]{2}{*}{2} & & & \\
\hline Fallesbanken & 1 & & & & \\
\hline Arbejdernes Landsbank & 1 & 5 & 5 & 5 & Arbejdernes Landsbank \\
\hline Jyske Bank & 0 & \multirow[t]{2}{*}{4} & \multirow[t]{2}{*}{4} & \multirow[t]{2}{*}{4} & \multirow[t]{2}{*}{ Jyske Bank } \\
\hline Finansbanken & 2 & & & & \\
\hline Alm. Brand Bank & 0 & 0 & 3 & 1 & Alm. Brand Bank \\
\hline Sparbank & 0 & 0 & 2 & 1 & Sparbank \\
\hline Banker og sparekasser & 238 & 188 & 124 & 92 & \\
\hline Asserballeskov Andelskasse & 1 & 1 & \multirow[t]{2}{*}{2} & \multirow[t]{2}{*}{4} & \multirow[t]{2}{*}{ Andelskassen Alssund } \\
\hline Sundeved Andelskasse & 1 & 1 & & & \\
\hline Tandslet Andelskasse & 2 & 3 & 3 & \multirow[t]{2}{*}{6} & \multirow[t]{2}{*}{ Andelskassen Sanderjylland } \\
\hline Tinglev Andelskasse & 1 & 1 & 2 & & \\
\hline Romø Andelskasse & 1 & 1 & 1 & 2 & Jernved-Romø Andelskasse \\
\hline J.A.K. Andelskasse Rødding & 1 & 1 & 1 & 0 & \\
\hline Total, inkl. andelskasser & 245 & 196 & 133 & 104 & \\
\hline
\end{tabular}

Filialantallet i 2009 er pr. august måned. Andringer annonceret herefter er ikke medtaget eller omtalt.

Sparekassen Sønderjylland, der fusionerede med Sydbank, forsvandt også Sparekassen Højer i 1990 via fusion med Bikuben. Tilbage var så otte sønderjyske institutter - tre banker og fem sparekasser.

De to megafusioner i 1990 betød bl.a., at Sønderjyllands førhen 
største og stadig dominerende udefra kommende bank, Kjøbenhavns Handelsbank, blev en del af Den Danske Bank. Endvidere forsvandt skiltene med Privatbankens, Andelsbankens og SDS' bomærker, der blev erstattet af Unibank-navnet. Sparekassen Sydjylland, der var en dominerende spiller i den nordlige del af Sønderjylland, måtte i 1991 give op og blev overtaget af Bikuben, hvis position i landsdelen således yderligere blev styrket. Bikuben overtog i 1995 også Girobank, der var etableret i 1991 via en privatisering af det statslige postgirosystem, og som opererede fra landets posthuse. Bikuben/Girobank videreførtes under navnet BG Bank. Hermed forsvandt den sidste "invadør-sparekasse « i Sønderjylland ${ }^{19}$. På banksiden var der nu syv institutter med hjemsted uden for landsdelen: Den Danske Bank, Unibank, BG Bank, Jyske Bank og Arbejdernes Landsbank samt Alm. Brand Bank og Sparbank (Skive) ${ }^{20}$.

Med disse ændringer kom filialrationaliseringen for alvor i gang, jf. skema 2. Fra 1988 til 1997 reduceredes filialantallet med en tredjedel - fra 188 til 124. De store bidragydere var naturligt nok igen fusionsinstitutterne: Sydbank Sønderjylland med 32, Den Danske Bank med 15 (en kontant halvering), Bikuben med 12 og Unibank med ti.

Rationaliseringen gik især ud over dels en række mindre samfund og landsbyer, dels de supplerende byfilialer, som var etableret $\mathrm{i}$ 60'erne og 70'erne i takt med nye bolig- og villakvarterers og hertil knyttede mindre butikscentres opståen. Automat- og elektronisk selvbetjening vandt for alvor frem i denne periode, hvor også de første pc-bankløsninger til privatkunder blev sat i drift.

Alt i alt var 15 banker og sparekasser repræsenteret i Sønderjylland i 1997.

Det var, som det fremgår, de store institutter, der påtog sig opgaven at gøre pengeinstitutlandskabet lidt mere overskueligt. Lokale filialtilpasninger og -lukninger har ekstrem offentlig bevågenhed - og slet ingen folkelig opbakning. Det kostede for de store på privatkundeantal, forretningsomfang og markedsandele. De mindre lokale institutter havde medvind - også fordi konjunkturerne generelt var opadgående. I en række tilfælde fulgtes en stor banks filiallukning af et lokalt instituts filialåbning samme sted - og undertiden i de samme lokaler.

Alm. Brand Banks og Sparbanks indtog i Sonderjylland i 90'erne afspejler denne udvikling. Men de tilbageværende lokale sønderjyske institutter var også med på vognen - og fortsatte i øvrigt hermed helt frem til 2007, jf. nedenfor. 


\section{Det seneste tiår}

Forandringstempoet i finansverdenen har været uændret højt siden slutningen af 90 'erne. På det strukturelle plan gik den ene af de to danske mega-banker, Unibank, i 1999 ind i den pan-nordiske konstellation Nordea. Og den anden store danske spiller, som nu kort og godt hedder Danske Bank, blev endnu større på hjemmebanen, da banken i 2001 overtog BG Bank og Realkredit Danmark. En fusion, der sendte bank-markedsandelen op over de $40 \%$, og som derfor med begrundet bekymring for markedsdominans - blev fulgt tæet til dørs af konkurrencemyndighederne. Senere har Danske Bank fortsat ekspansionen uden for landets grænser - via markante bankovertagelser i bl.a. Finland og Irland.

Samkøringen mellem Danske Bank og BG Bank skete ikke på sædvanlig kontant Danske Bank-vis. BG Bank-brandet blev i fem år opretholdt som en specialbanktype med adresse til særlige kundesegmenter. En kostbar, men samtidig i situationen sikkert klog fusionsmodel. På fusionstidspunktet havde de tilbageværende lokale selvstændige banker og sparekasser landet over i en årrække fisket $\mathrm{i}$ rørte vande efter mega-fusionerne, jf. også oven for. Den »langsomme" indkøring af BG Bank med denne banks »blødere profil« har givet fastholdt mange kunder i Danske Bankkoncernen $^{21}$.

Den Danske Bank, vi i dag møder i Sønderjylland, bygger i høj grad på den gamle Kjøbenhavns Handelsbank og Bikuben. Banken har 15 afdelinger i landsdelen - i Haderslev, Vojens, Jels, Christiansfeld, Agerskov, Toftlund, Tønder, Skærbæk, Løgumkloster, Aabenraa, Rødekro, Padborg, Gråsten, Sønderborg og Nordborg. Af de 40 selvstændige institutter, der opererede i Sønderjylland i 1968, er de 16 direkte eller indirekte - overtaget af Danske Bank. De overtagne institutter hørte hjemme i 13 forskellige sønderjyske byer/samfund og seks af disse - Emmerlev, Daler, Døstrup, Ulkebøl, Skodborg og Нøjer - har i dag slet ingen pengeinstitutafdeling.

Nordeas sønderjyske tilstedeværelse i dag har sit afsæt primært i Privatbankens overtagelse af Haderslev Bank i 1970 og i Andelsbankens indtræden i Unibank-fusionen i 1990. Nordea har 13 afdelinger i Sønderjylland - i Haderslev, Vojens, Christiansfeld, Rødding, Gram, Toftlund, Aabenraa, Rødekro, Padborg, Broager, Sønderborg, Guderup og Nordborg. Det bemærkes, at Nordea efter i 2008 at have lukket 
Løgumkloster-afdelingen slet ikke er repræsenteret i det gamle Tønder Amt.

Både Arbejdernes Landsbank og Jyske Bank er fortsat i Haderslev, Aabenraa og Sønderborg. Landsbanken er endvidere i Vojens og Nordborg og Jyske Bank i Padborg. Endelig har Alm. Brand Bank opretholdt sit kontor i Sønderborg, og Sparbank sin afdeling i Haderslev. Begge har droslet den sønderjyske tilstedeværelse ned.

\section{De lokale, mindre institutter}

Tiåret 1997-2007 prægedes i øvrigt af de mindre lokale institutters ekspansion. Det foregik i ly af generelt ekstraordinært gode finanskonjunkturer i tiårets sidste halvdel og i ly af institutternes billige adgang til danske pengeinstitutters fælles infrastruktur (primært it, betalingsformidling og værdipapirafvikling) - og i ly af specielt en del sparekassers frihed for markedsfokus på konkurrencedygtig egenkapitalforrentning (shareholder value).

De i Sønderjylland i 1997 tilbageværende seks mindre, lokale institutter deltog alle i filialekspansionen.

Broager Sparekasse var tilbage i 1962 via fusion med den lokale sparekasse blevet repræsenteret i Nybøl, og sparekassen åbnede i 1969 kontor i Egernsund og i 1971 i Skelde. Sidstnævnte blev lukket i 1992. Sparekassen åbnede i 1994 i Sønderborg og i 1997 i Aabenraa. Egernsund-afdelingen blev i 2004 flyttet til Gråsten og Nybøl-afdelingen nedlagt i 2007. Primo 2009 overtog Broager Sparekasse Sparbanks afdeling i Sønderborg, som sammenlægges med den eksisterende Sønderborg-afdeling. Sparekassen har således i dag fire afdelinger.

Frøs Herreds Sparekasse med hjemsted i Rødding var i mange år repræsenteret med en afdeling i Gram og kontorer i Lintrup, Sdr. Hygum og Øster Lindet samt i en periode i Jels. Kontorstederne blev afviklet i perioden 1986-96. Sideløbende hermed og i årene derefter har sparekassen etableret sig uden for Frøs herred - og også uden for Sønderjylland: i Vejen (1990), Ribe (1992), Haderslev (1996), Esbjerg (2000), Kolding (2002), Aabenraa (2004) og Sønderborg (2006). Frøs Herreds Sparekasse har således i dag i alt ni afdelinger, heraf fire nord for Kongeåen.

Sparekassen Bredebro var tilbage i 70'erne repræsenteret i de gamle "moderbyer« - Bredebro, Ballum og Visby - samt i Sølsted. Sidstnævnte afdeling blev lukket i 1978. I perioden 2001-2007 åbnede sparekassen afdelinger $\mathrm{i}$ Tønder, Skærbæk og Toftlund. Ved årsskiftet 
2008/09 lukkedes afdelingerne i Ballum, Visby og Toftlund, og Sparekassen Bredebro har herefter tre afdelinger.

Sparekassen Løgumkloster havde tilbage i tiden afdelinger i Løgumgårde, Øster Højst og Bedsted. Løgumgårde blev lukket i 1991 og Øster Højst og Bedsted i 2005. Sparekassen åbnede afdeling i Hellevad i 2000, i Tønder i 2001 og i Rødekro i 2004.12003 blev Ravsted Sparekasse, der siden 1992 havde haft filial i Bolderslev og siden 2001 i Tinglev, overtaget. Tidligt i 2009 blev en lukning af afdelingerne i Ravsted og Bolderslev annonceret, og kort tid derefter kom udmeldingen om, at Sparekassen Logumkloster med sine $i$ alt fem afdelinger overtages af Den Jyske Sparekasse med hjemsted i Grindsted. Der er dermed sagt farvel til endnu en lokal sønderjysk spiller. Overtagelsen gav naturligt anledning til kommentarer om, hvorvidt en sammenslutning med andre sønderjyske lokal-sparekasser kunne have været et alternativ. Nævnt som mulige "makkere " blev både Broager og Bredebro. Men ikke Frøs. Hertil er at sige, at Frøs Herreds Sparekasse længe har været det eneste tilbageværende selvstændige pengeinstitut i det gamle Haderslev Amt. Og på de kanter har de jo ikke for vane at indgå i sønderjyske sammenslutninger.

Tønder Bank var i mange år repræsenteret i Bylderup-Bov, Tinglev og Højer. Sidstnævnte filial blev lukket i 2004. Banken åbnede i 1994 afdeling i Skærbæk, i 1997 i Toftlund, i 2000 i Løgumkloster og Vojens, og i 2003 i Rødekro. Banken har i dag, ud over de otte sønderjyske afdelinger, også en afdeling i Vejen samt kontorer i København og Århus.

Aabenraa Kreditbank har siden 1939 haft afdeling i Sønderborg og indtil 1977 agenturer i Kruså og Uge og i årene 1978-90 i Padborg. Samtidig med navneskift til slet og ret Kreditbanken åbnede banken i 2001 i Haderslev og har således i dag tre afdelinger.

\section{Andelskasser}

Den første andelskasse i Danmark blev stiftet i $1915^{22}$. Men andelskassebevægelsen har i Sønderjylland dybere og ældre rødder, idet der her allerede i slutningen af 1800-tallet blev oprettet spare- og lånekasseforeninger efter den tyske Raiffeisenkasse-model. Ved Genforeningen i 1920 blev 26 sådanne omdannet til danske andelskasser. Allerede i 1930 var antallet dog "skrumpet til en halv snes stykker, hvoraf flertallet befinder sig i Sønderborg Amt« (Hübbe 1931 s. 29).

Fremme i slutningen af 1960'erne var der på landsplan 55 og i 
Sønderjylland fem selvstændige andelskasser. Mange andelskasser, herunder de fem sønderjyske, gik i 1986 ind i Sammenslutningen Danske Andelskasser (SDA). Under SDA-paraplyen udgør disse fem - oprindeligt med hjemsteder i (og navne efter) Tandslet, Asserballeskov, V. Sottrup, Tinglev og Rømø - også i 2009 rygraden i den sønderjyske andelskassetilstedeværelse. De har gennem årene ekspanderet via filialetableringer, og inden for de seneste år er de alle indgået $i$ fusioner.

Tandslet Andelskasse havde kontor i Ertebjerg i årene 1970-88, i Lysabild i årene 1984-99 og åbnede i Høruphav i 1995 og i Sønderborg i 2001. Tinglev Andelskasse åbnede en filial i Rens i 1990. De to andelskasser fusionerede i 2007 til Andelskassen Sønderjylland, som - nu med hovedkontor i Sønderborg - omfatter i alt seks afdelinger, idet andelskassen primo 2009 i umiddelbar forlængelse af Sparekassen Løgumklosters exit åbnede et såkaldt servicekontor i Ravsted.

Asserballeskov Andelskasse og Sundeved (V. Sottrup) Andelskasse blev sammensluttet i 1994 og ændrede i 2001 navn til Andelskassen Alssund. Andelskassen fik i 2003 hovedkvarter i en nyåbnet afdeling i Augustenborg. Samtidig blev den hidtidige hovedafdeling i Asserballeskov lukket/flyttet til Fynshav, som imidlertid i 2007 blev lukket igen. I dag opererer andelskassen med tre filialer - ud over V. Sottrup også Nordborg (åbnet i 2005) og Gråsten (åbnet i 2007).

Endelig er Rømø Andelskasse siden 2006 del af Jernved-Rømø Andelskasse, som har hovedkontor i Gredstedbro. Andelskassen åbnede i 2008 filial i Tender.

Der er således anno 2009 repræsenteret tre SDA-andelskasser i Sønderjylland med i alt 12 afdelinger i landsdelen.

Afslutningsvist skal det noteres, at J.A.K.-bevægelsen, i forlængelse af at J.A.K. Banken i 1973 blev overtaget af Bikuben, landet over startede en stribe nye J.A.K. fælles- og andelskasser. I Sønderjylland en enkelt - i 1974 i Rødding. Den videreførtes til 2008, hvor J.A.K. Andelskasse Rodding blev nedlagt. Virksomheden er overtaget af Folkesparekassen i Silkeborg ${ }^{23}$.

\section{Sydbank}

Sydbank kom efter den markante omstrukturering midt i 90'erne tilbage på vækst- og resultatsporet, og banken er i dag Danmarks fjerdestørste og praktisk taget landsdækkende. I 2002 overtoges Odensebanken Egnsbank Fyn og i 2008 bankTrelleborg med hjemsted i Slagelse og med bred repræsentation på Sjælland. 
Sydbanks sønderjyske tilstedeværelse er - væsentligst via hjemstedet i Aabenraa, hvor der beskæftiges 600 medarbejdere - markant. Men forretningsmæssigt ligger bankens tyngdepunkter andre steder $i$ landet (og syd for grænsen). Bankens filialantal er i dag nogenlunde det samme som i slutningen af 1990'erne - 115. Ikke desto mindre har Sydbank i perioden siden 1997 afviklet 35 filialer, heraf 12 i Sønderjylland, hvor der nu "kun « findes 25 Sydbank-afdelinger - i Aabenraa, Løjt, Rødekro, Kliplev, Padborg, Kruså, Gråsten, Tinglev, BylderupBov, Tønder, Bredebro, Skærbæk, Haderslev, Vojens, Broager, Sønderborg, Augustenborg, Høruphav, Guderup og Nordborg. Sydbank har som omtalt 14 lokale sønderjyske "rødder" - fire lokale banker og ti sparekasser, hjemmehørende i 11 forskellige byer i landsdelen. Fire af disse - Ketting, Brøns, Møgeltønder og Hostrup - har i dag ikke nogen pengeinstitutafdeling.

\section{Hvorfor gik det, som det gik?}

De overordnede drivkræfter bag sammenlægnings- og omstruktureringsbølgerne omkring 1970 og 1990 er berørt foran - men er i øvrigt særdeles vel beskrevet $\mathrm{i}$ den omfattende generelle finanslitteratur om perioden ${ }^{24}$.

Det interessante for mig er, hvorfor den sønderjyske struktur blev som den blev, herunder hvorfor enkelte sønderjyske banker og sparekasser valgte/evnede at holde sig fri af en udvikling, hvor hele "systemet« ellers råbte på konsolidering, og hvor slagordet syntes at være, at "stort er godt, og småt er umuligt«.

Og jeg skal straks vedgå, at jeg - naturligvis - ikke har svar på spørgsmålene. Gennemførte fusioner har altid en god, officiel begrundelse. Men i hvor høj grad det er den fulde sandhed bag sammenslutningen, ved kun få. Ikke-gennemførte fusioner ved offentligheden sjældent noget om - og end mindre om motiverne bag. Eksempelvis har Sydbank gennem de seneste 40 år lagt navn til godt en halv snes sammenslutninger/fusioner, og i alle tilfælde kan man via fondsbørsmeddelelser o.l. finde gode forklaringer på "projektet ", set fra begge sider. Men er det hver gang den reelle og fulde baggrundshistorie, vi får? Og hvad med de andre fusionsprojekter, som Sydbank - måske har haft på tegnebrættet, men som ikke blev til noget? Med hvem hvorfor - og hvorfor ikke?

Det er med andre ord halsløs gerning at stræbe efter den endegyl- 
dige forklaring på, hvorfor det gik, som det gik. Men det skal nu ikke afholde mig fra at lede efter og fremdrage nogle mønstre bag 40 års forandringer i det sønderjyske pengeinstitutlandskab.

Fusioner er ikke romantiske alliancer. Snarere tværtom. Bagved ligger derimod barsk, typisk økonomisk, nødvendighed eller velovervejet, normalt forretningsstrategisk, kalkule. I sidste ende drejer det sig om, hvad der er og fremadrettet, bredt forstået, vil være mest lønnende for virksomhedernes ejere, kunder, medarbejdere og - ikke mindst - ledelse. I den forbindelse spiller personlige forhold - menneskelige sympatier eller antipatier og adfærdsmønstre en betydelig, ofte afgørende, rolle. Der kan da godt være indbygget elementer af f.eks. lokalpatriotisk idealisme i beslutningsgrundlaget og afgørelserne, men landdelsinteresser står reelt set alene i første række, hvis de harmonerer med andre taktisk/strategiske eller personlige synspunkter på og holdninger til en sammenslutning.

På sin vis kan man derfor vælge at finde det imponerende, at den første fusionsbølge i Sønderjylland resulterede i, at 14 af 40 sparekasser og banker fandt sammen i to regionale konstellationer: Sparekassen Sønderjylland og Sydbank. Det må formodes at afspejle en tro hos bagmændene på, at store landsdelsinstitutter også ud fra en forretningsmæssig synsvinkel ville være en rigtig løsning på den fremadrettede sønderjyske finansforsyning. Det er yderligere værd at notere, at præcis halvdelen af de oprindeligt 40 sønderjyske banker og sparekasser endnu i dag er på »sønderjyske hænder«.

Modsat illustrerer forløbet også, at sønderjysk fællesskab, baseret på en særegen landsdelsidentitet, ikke - slet ikke - er noget naturgivent. Måske snarere tværtimod. I Sønderjylland står man, af åbenlyse historiske årsager, sammen udadtil. Men ikke indadtil. Konkurrencen og modsætningerne mellem de forskellige dele af regionen er og har altid været knivskarp - næsten uforsonlig. Det gælder mellem landsdelens købstæder og ikke mindst indbyrdes mellem de tre store østkystbyer - Sønderborg, Aabenraa og Haderslev. Det gælder mellem syd og nord - og mellem "den rige østkyst « og den fattigere vesteregn. Og det gælder ikke kun, når pengeinstitutstrukturen skal fastlægges. Andre eksempler er elitesport og sygehusvæesen. Placering af hovedsæder har været et stort - og egentlig ganske naturligt stridsspørgsmål. Her er Sønderjyllands Amtskommune og Sydbank som begge fik hjemsted i Aabenraa - oplagte eksempler.

Min undersøgelse dokumenterer, at det gamle Haderslev Amts 
pengeinstitutter rimelig konsekvent har fravalgt sønderjyske fusionspartnere. 11 ud af 12 er i dag dele af Danske Bank og Nordea, og det 12. institut - Frøs - er fortsat sig selv med aktivitet både syd og nord for Kongeåen. Et lignende billede ses $\mathrm{i}$ den vestligste del af det nordlige Sønderjylland, egnen fra omkring Skærbæk og nordpå, som tilbage i det 19. århundrede indgik i det daværende Haderslev Amt. Ud af fem selvstændige institutter $i$ dette område $i$ slutningen af 1960'erne indgik og forblev kun et, Brøns Sparekasse, i en sønderjysk fusion (Sparekassen Sønderjylland, nu Sydbank). Man fristes til at konkludere, at jo nærmere Kongeåen, man er, jo mindre trækker det sønderjyske - $\mathrm{i}$ hvert fald når der er tale om pengeinstitutter. Men det kan jeg ikke dokumentere. Der kan jo ligge helt andre årsager - eller ganske enkelt tilfældigheder - bag.

Og det kan heller ikke dokumenteres, om sønderjydernes pengeinstitutforsyning ville have været markant anderledes, endsige bedre, hvis de lokale fusioner omkring 1970 - Sparekassen Sønderjylland og Sydbank - havde omfattet hele landsdelen, altså også det gamle Haderslev Amt. Men den Sydbank, der nu står tilbage som det store lokale sønderjyske institut, ville uomtvisteligt have haft en stærkere markedsposition i regionen også omfattende den nordlige del, hvis Sparekassen Haderslev var kommet med i Sparekassen Sønderjylland og/eller Haderslev Bank var kommet med i Sydbank.

Men sådan blev det ikke. Man kan naturligvis kun gisne om, hvordan en af sønderjysk bankvæsens "grand old men ", Haderslev Bankdirektøren Chr. Hübbe (1868-1945), ville have set på, at den sønderjyske regionalbank blev uden Haderslev-deltagelse. Hübbe, der bl.a. er forfatter til den foran omtalte artikel i Sønderjyske Årbøger 1931 om landsdelens pengevæsen $\mathrm{i}$ de forste 10 år efter Genforeningen, var $\mathrm{i}$ 1909 en af hovedmændene bag oprettelsen af den senere store Sønderborg-bank Folkebanken for Als og Sundeved. Ifølge bankens 50 års jubilæumsskrift fra 1959 opfordredes Hübbe til at etablere en filial af Haderslev Bank i Sonderborg, som stod uden en ren dansk bank. Men Hübbe fandt ikke, at det var den rette løsning, og tog i stedet initiativ til at samle lokale kræfter bag oprettelsen af en helt ny dansk bank i Sønderborg - det der blev til Folkebanken for Als og Sundeved. Hübbes (og dermed Haderslev Banks) direkte og konstruktive indsats og medvirken blev aktivt understettet af Den Nordslesvigske Folkebank i Aabenraa og Tønder Landsmandsbank ${ }^{25}$. Da de fire sønderjyske købstadsbanker sammen med Gråsten Bank (etableret i 1920 
med baggrund i den gamle stedlige sparekasse og med Otto Paasch, som kom fra Haderslev Bank, som første direktør) 60 år senere skulle finde sammen til én sønderjysk bank, var det Hübbes bank, der faldt fra.

Her ved vi positivt, at den udløsende faktor var et fusionsoplæg, der indebar, at Haderslev Banks aktionærer, grundet (målt med den tids alen) store tab i banken i de forudgående år, kun blev tilbudt en aktie $i$ den sammensluttede bank for hver to egne aktier, hvor ombytningsforholdet $\mathrm{i}$ øvrigt var 1:1. Udsigten til en sådan udstilling af relativ svaghed drev Haderslev Bank i armene på Privatbanken. Der var ganske vist blandt Sydbank-stifterne fortalere for, at man med sigte på at realisere den komplette sønderjyske regionalbank-løsning skulle lade fem og syv være lige og tage Haderslev Bank med på samme vilkår som de øvrige banker. Så store penge drejede det sig jo heller ikke om. Men "dette synspunkt fandt ikke tilslutning ", som Sydbanks senere mangeårige formand, Erik Jessen, lakonisk udtrykker det $\mathrm{i}$ sine erindringer ${ }^{26}$.

Set i bakspejlet var Sydbank-stifternes håndtering i 1969-70 af Haderslev Bank et strategisk fejlgreb.

Der foreligger mig bekendt ikke nogen tilsvarende officiel forklaring på, at Sparekassen Haderslev i 1972 valgte at gå nordpå og ind i sammenslutningen Sparekassen Sydjylland og således fravalgte det åbenlyse sønderjyske alternativ: Sparekassen Sønderjylland. Spørger man sig for hos folk, der husker forløbet, er forklaringen enslydende: disharmoni på højt ledelsesniveau mellem Sparekassen Sønderjylland og Sparekassen Haderslev - og et, set bl.a. i den sammenhæng, mere tillokkende sydjysk perspektiv. Jeg kan kun gisne om, hvorvidt disharmonien havde baggrund i personlige, regionalpolitiske eller helt andre forhold.

Frøs Herreds Sparekasse valgte (som en af få sparekasser) omkring 1970 at forblive $\gg$ sin egen $«-$ og er det stadig. I sparekassens 100 års jubilæumsbog (Sørensen, 1972, s. 81-83) er man temmelig stilfærdig omkring emnet. Det sønderjyske sparekassesamarbejde ${ }^{27}$ og de enkelte (mindre) sparekassers individuelle bankforbindelse nævnes som baggrundsstøtte for selvstændige sønderjyske sparekasser. Der rundes af på denne måde (ibid. s. 83): "I de større sammenslutninger bliver tyngdepunktet naturligt nok på østkysten med de rigere muligheder i erhvervsmæssig henseende og den større folkemængde, og en vestbo kan godt tvivle på, hvorvidt østkystens penge rækker ud til 
vestkysten. Bedst vil det sikkert gå med egne kræfter og et vist samarbejde. Det står fortsat til egnens befolkning, om det skal lykkes, som det er lykkedes gennem 100 år.«

Her dukker modsætningsforholdet mellem øst og vest i Sønderjylland op. Der var en udtalt bekymring for, at man ville blive »kørt over « ude vestpå, hvis magten blev flyttet ud til en af østkyst-købstæderne. Den samme argumentation blev i øvrigt benyttet i debatten om Sparekassen Løgumklosters ikke-vedtagne fusion med Sparekassen Sydjylland i 1976. Ifølge avisreferat herom gjorde modstanderne bl.a. gældende, at der »ingen garanti [er] for, at der vil være penge at hente fra den rige østkyst ${ }^{28}$.

I 125 års jubilæumsskriftet fra Frøs Herreds Sparekasse (Ravn, 1997 s. 19) har tonen ændret sig. Man er, som det hedder på nudansk "klar i spyttet « - også bagudrettet. Det noteres således, at 100 års jubilæet i 1972 blev markeret med en meget konkret og håndfast selvstændighedserklæring - i form af en stor udvidelse af hovedkontoret i Rødding. Baggrunden for dette stemningsskifte er givet, at Rødding-sparekassen siden slutningen af 70 'erne fra topledelsen og hele vejen gennem organisationen har været gennemsyret af en ubændig, men samtidig klogt håndteret, trang til at ville og kunne selv.

Det må klart konstateres, at "missionen er lykkedes« for Frøs. $\mathrm{Og}$ denne nordligt i Sønderjylland beliggende selvstændige sparekasse føler sig i dag nok snarere som et sydjysk end et sønderjysk institut. Om man her senest har fået buddet, da Sparekassen Løgumkloster kom i spil, ved jeg ikke. Men mon ikke det for Frøs er mere interessant at udbygge forretningen i Esbjerg, Kolding og de sønderjyske østkyst-købstæder end i Løgumkloster og Hellevad?

Frøs Herreds Sparekasse er i øvrigt det eneste ud af oprindeligt 52 pengeinstitutter, der i dag optræder under samme navn - om end ikke i samme skikkelse - som i 1968.

Broager Sparekasse har om sin fortsatte selvstændighed formuleret sig således (Hagedorn m.fl., 1995 s. 20): "Bestyrelsen har løbende fulgt og overvejet situationen [i lyset af, at antallet af selvstændige sparekasser i Sønderjylland i løbet af de foregående 25 år var kraftigt reduceret], men har ikke fundet, at en fusion kunne forbedre vore muligheder for tiden. Vi har valgt at koncentrere os om det, vi er gode til, og undlade de mere avancerede forretninger, ligesom vi er forsigtige med at gå ind i for store engagementer.«

Jeg har i offentligt tilgængeligt materiale ikke fundet lignende klare 
tilkendegivelser fra Sparekassen Bredebro. Men punkt 1. i sparekassens værdigrundlag - „Vi vil være Vesteregnens bedste pengeinstitut « - udtrykker ambitioner og selvbevidsthed. Og kendsgerningen er i hvert fald, at Sparekassen Bredebro i dag er det eneste selvstændige pengeinstitut, der koncentrerer sig helt og fuldt om Vesteregnen.

Man har i sparekasserne med hjemsted i Broager og i Bredebro gerne villet selvstændigheden - uden at have udelukket alternativet. Denne grundholdning har $\mathrm{i}$ forening med omstændighederne og forretningsførelsen muliggjort, at der stadig er lokale institutter de to steder.

At Tønder Bank og Kreditbanken i Aabenraa fortsat er her, skal givet bl.a. ses på baggrund af bankernes rødder i det tyske mindretal. Det har undervejs hjulpet dem over de problemer, de er stødt på. Den tredje "tyske« bank i landsdelen var jo Haderslev Creditbank, som tilbage i 1985 blev overtaget af Den Danske Bank(!). Den Danske Bank var i forvejen relativt betydende aktionær i Haderslev Creditbank og manglede på daværende tidspunkt rigtigt fodfæste i Haderslev. Man kunne og var villig til at betale prisen - hvilket ingen andre (og slet ikke Aabenraa Kreditbank, som ellers ville have været den "politisk korrekte« fusionspartner) måtte formodes at kunne.

\section{Afrunding}

Det sønderjyske pengeinstitutlandskab er blevet noget mere overskueligt i løbet af de seneste 40 år.

Over 50 repræsenterede institutter med flere end 200 bemandede betjeningssteder fordelt på 100 byer er reduceret til 16 institutter med 104 betjeningssteder fordelt på 33 byer. Tiderne med tre-fire pengeinstitutafdelinger i mindre bysamfund er en saga blot. Det gælder bl.a. Sommersted, Over Jerstal, Varnæs, Højer, Øster Lindet, Skodborg og Arnum, som er helt »pengeinstitutløse« $i$ dag. Det samme gælder 12 byer, der i 1968 hver især var hjemsted for en af de daværende selvstændige sparekasser.

Pengeinstitutafdelingerne er i dag i højere grad end tidligere samlet i landsdelens største byer. I 1968 var 30 af Sønderjyllands daværende 221 pengeinstitutafdelinger - 14\% - placeret i købstæderne Haderslev, Aabenraa, Sønderborg og Tønder. I dag er det tilsvarende antal 36 og procentandelen 35. Denne strukturforandring er sket på trods af, at de større banker har reduceret deres tilstedeværelse netop i købstæ- 
Figur 4: Det sønderjyske pengeinstitutlandskab anno 2009

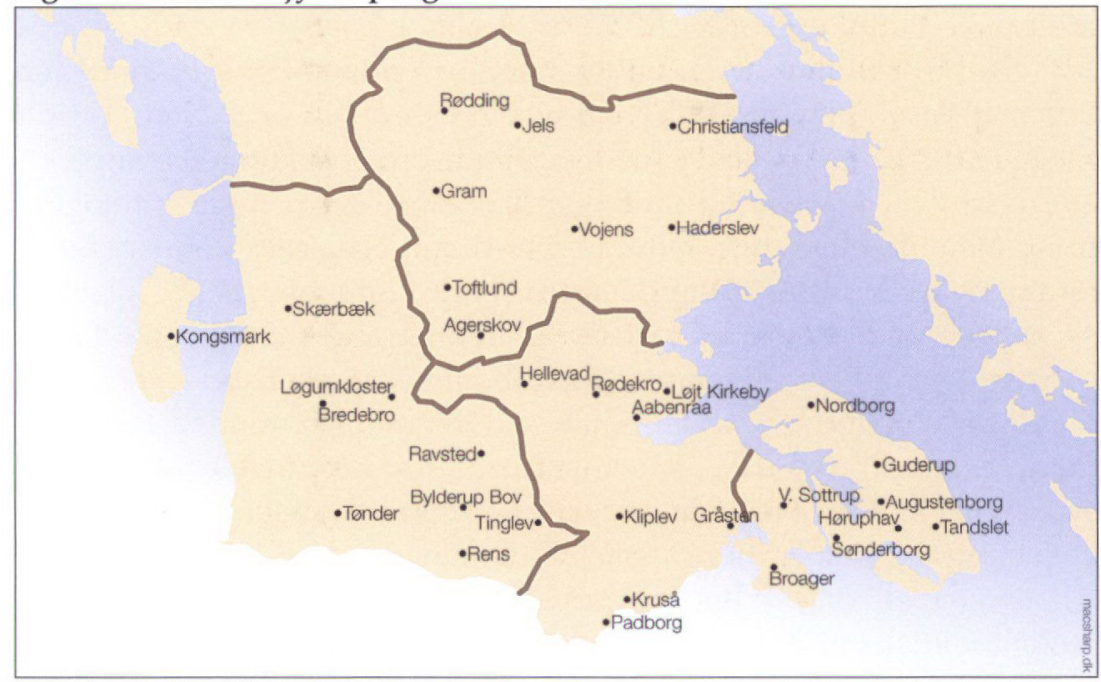

Kortet viser de 33 byer/lokaliteter $i$ Sonderjylland, hvor der medio 2009 er bemandede pengeinstitut-betjeningssteder: I alt 16 pengeinstitutter med tilsammen 104 betjeningssteder spredt på de viste 33 byer i landsdelen - praktisk taget ligeligt fordelt mellem de fire gamle amter.

derne fra tidligere ofte 3-4 afdelinger til nu typisk én. Denne ene afdeling er til gengæld udstyret med faglig kompetence til de fleste former for bankrådgivning, hvilket i stadigt stigende omfang vil være det eneste, der vil kunne retfærdiggøre opretholdelsen af bemandede bankbetjeningssteder.

De fire gamle sønderjyske amter - Haderslev, Aabenraa, Sønderborg og Tønder - var op til 1970 nogenlunde ensartet forsynet med pengeinstitutafdelinger. Men mens de tre øvrige amter havde 10 eller flere - typisk mindre - selvstændige sparekasser og banker, havde det daværende Aabenraa Amt kun fire selvstændige institutter - Sparekassen for Aabenraa By og Amt, Den nordslesvigske Folkebank, Gråsten Bank og Aabenraa Kreditbank. De er alle endnu i dag på »sønderjyske hænder « - de tre førstnævnte i Sydbank og Kreditbanken fortsat som sig selv. Kun en ud af 10 banker og sparekasser fra det gamle Sønderborg Amt blev del af en »invadør «, nemlig sparekassen i Ulkebøl, som er landet i Danske Bank. Halvdelen (helt præcist 10) af det gamle Tønders 19 selvstændige pengeinstitutter er i dag på "uden-amtslige« hænder, mens som nævnt ikke færre end 11 af 
Haderslev Amts oprindelige 12 institutter er indgået i det, der i dag er Danske Bank og Nordea.

Pengeinstitutlandskabet er altså markant ændret - og udtyndet. Men det afspejler jo blot, at verden i det hele taget også er forandret. Helt tilbage i 1920'erne var der, jf. nedenstående om udviklingen i Varnæs, i en landsby med under 500 indbyggere ikke kun tre pengeinstitutagenturer, men blandt mange andre borger-tilbud også seks købmandsforretninger. Omkring 1970 var der stadig både købmænd, bager, slagter og pengeinstitutfilialer - $\mathrm{i}$ Varnæs og i mange andre småbyer. I dag er der hverken det ene eller andet. På købmandssiden er serviceniveauet markant forringet, selvom køleskab og dybfryser har mindsket behovet for de daglige indkøb. På pengeinstitutsiden er det nok blevet mere besværligt at komme i banken på gammeldags facon. Men de alternative betjenings- og ekspeditionsløsninger er mange og veludviklede. Sparekassebogen er i dag på det nærmeste en anakronisme.

Rent faktisk har over $60 \%$ pct. af danskerne - og af sønderjyderne i dag deres egen hjemmebank i form af en netbank-forbindelse. $\mathrm{Og}$ den andel når meget højere op i løbet af den næste halve generation. Via netbanken kan en række almindelige ekspeditioner foretages hjemmefra. Langt de fleste privatkunder er endvidere udstyret med mindst et betalings- og hævekort, der næsten overflødiggør kontanter i tegnebogen. Kortet kan bruges som betalingsmiddel i forretninger og til kontanthævninger $i$ de flere end 3.000 pengeautomater, der er til rådighed, praktisk taget døgnet rundt - dels i tilknytning til de tilbageværende knap 2.000 filialer, dels på andre lokaliteter, hvor mange mennesker færdes. Regningsbetalingerne foregår i vid udstrækning pr. automatik via et velfungerende Betalingsservice-system. Elektronik, fjern- og selvbetjening af mange dagligdags bankforretninger har haft den konsekvens, at ens pengeinstitut ikke behøver at ligge lige om hjørnet. Ergo: meget mindre kundebehov for den lokale filial.

Og set fra udbudssiden er grænserne for pengeinstitutternes markedsområder meget videre end førhen. Et eksempel er Nykredit-koncernen, der bl.a. driver en stor landsdækkende privat-bankforretning, indtil for nylig ${ }^{29}$ i princippet udelukkende baseret på internetbetjening, men med en vis kontaktmæssig opbakning fra 49 »boligbutikker« - filialer - landet over, heraf i øvrigt tre i Sønderjylland: i Haderslev, Aabenraa og Sønderborg.

Når der næste gang gøres status på pengeinstitutlandskabets foran- 
dringer i Sønderjylland - dækkende årene efter den aktuelle finanskrise - vil der givet være endnu færre af det hele: antal repræsenterede institutter, antal sønderjyske institutter og antal bemandede betjeningssteder. Men også fremadrettet skal kundebehovene for pengeinstitutydelser nok blive dækket på tidssvarende vis - også i Sønderjylland.

Varnas - et lille Korsbak

Mange sønderjyske byer - også de små - havde endnu sidst i 1960'erne eget pengeinstitut, typisk en lokal sognesparekasse. Og alternativt var mange af landsdelens småbyer vel forsynet med pengeinstitutkontorer eller "agenturer«. Et eksempel er landsbyen Varnæs, der ligger $i$ en naturskon egn ved sydsiden af Aabenraa fjord i en afstand af ca. $15 \mathrm{~km}$ til hver af de større byer Aabenraa, Sønderborg og Gråsten.

Varnæes er, uden for Sønderjylland, nok bedst kendt fra TV-serien "Matador « - som navnet på direktør-dynastiet i Korsbæk Bank. I »det virkelige liv « er der langt fra den fiktive sjællandske købstad Korsbæk til den mere beskedne, sønderjyske landsby Varnæs. Men man skal ikke overse, at småbyer som Varnæs langt op i det 20 . århundrede endnu osede af liv og foretagsomhed. Af Trap Danmarks 4. udgave fremgår, at der tilbage i 1925 i Varnæs by med 425 indbyggere - ud over kirke og skole - fandtes bl.a. seks købmandsforretninger, 25 håndværkere, andelsmejeri, gæstgiveri samt post-, telefon- og telegrafekspedition. $\mathrm{Og}$ tre pengeinstitutter: agenturer for Gråsten Bank, Nordslesvigsk Folkebank og Sparekassen for Aabenraa By og Amt. Der var således også rige valgmuligheder for bank- og sparekassekunderne.

Der var stadig tre pengeinstitutter i byen op til 1968. Gråsten Banks agentur var ganske vist lukket, men til gengæld havde Andelsbanken slået sig ned i Varnæs. Og da sparekasse-afdelingen lukkede i 1970, kom Handelsbanken til med bankbussen. Men inden 1980 var det slut. Da havde den sidste bank forladt modstykket til Korsbæks Algade - landsbyens »Wall Street«, der i dag hedder Varnæsvigvej. Og hvis du skal afregne med nogen i Varnæs, skal du tage kontanterne med. Der er hverken pengeautomat eller butikker i byen. 
Bilagsskema 1: Sonderiyske banker, sparekasser og andelskasser 1968, der fortsat i 2009 er del af pengeinstitutter hjemmehorende i Sonderjylland

\begin{tabular}{|c|c|c|c|}
\hline $\begin{array}{l}\text { Sonderjyske pengeinstitutter } \\
1968\end{array}$ & \multicolumn{2}{|c|}{$\begin{array}{l}\text { Sammenslutninger/overtagelser/navneændringer } \\
\text { 1968-2009 }\end{array}$} & Status 2009 \\
\hline Aabenraa Kreditbank (1926) & \multicolumn{2}{|c|}{ 2002: Navneandret til Kreditbanken } & Kreditbanken \\
\hline $\begin{array}{l}\text { Tonder og Omegns Bank } \\
\text { (1913) }\end{array}$ & \multicolumn{2}{|c|}{ 1985: Navneændret til Twnder Bank } & Tonder Bank \\
\hline $\begin{array}{l}\text { Den Nordslesvigske } \\
\text { Folkebank (1872) }\end{array}$ & \multirow{4}{*}{\multicolumn{2}{|c|}{ 1970: Sammensluttet til Sydbank }} & \multirow[t]{14}{*}{$\begin{array}{l}\text { Sydbank } \\
\text { (Aabenraa) }\end{array}$} \\
\hline Graasten Bank (1920) & & & \\
\hline $\begin{array}{l}\text { Folkebanken for Als og } \\
\text { Sundeved (1909) }\end{array}$ & & & \\
\hline $\begin{array}{l}\text { Tonder Landmandsbank } \\
\text { (1901) }\end{array}$ & & & \\
\hline $\begin{array}{l}\text { Sparekassen for Aabenraa By } \\
\text { og Amt (1818) }\end{array}$ & \multirow{10}{*}{$\begin{array}{l}\text { 1968: Sammensluttet } \\
\text { med Sparekassen } \\
\text { Sonderjylland } \\
\text { 1970: do. } \\
\text { 1971: do. }\end{array}$} & \multirow[t]{10}{*}{$\begin{array}{l}\text { 1990: Sparekassen } \\
\text { Sonderiylland } \\
\text { sammensluttet med } \\
\text { Sydbank }\end{array}$} & \\
\hline $\begin{array}{l}\text { Sonderborg Bys Sparekasse } \\
(1820)\end{array}$ & & & \\
\hline $\begin{array}{l}\text { Ketting og Omegns Sparekasse } \\
(1888)\end{array}$ & & & \\
\hline Tender Sparekasse (1820) & & & \\
\hline $\begin{array}{l}\text { Brøns Sogns Spare- og } \\
\text { Laanekasse (1883) }\end{array}$ & & & \\
\hline $\begin{array}{l}\text { Mogeltonder Sparekasse } \\
(1900)\end{array}$ & & & \\
\hline $\begin{array}{l}\text { Sparekassen for det sydlige } \\
\text { Als }(1896)\end{array}$ & & & \\
\hline $\begin{array}{l}\text { Spare- og Laanekassen for } \\
\text { Hostrup Sogn }(1844)\end{array}$ & & & \\
\hline Nordborg Sparekasse (1862) & & & \\
\hline $\begin{array}{l}\text { Spare- og Laanekassen for } \\
\text { Tinglev og omliggende sogne } \\
\text { (1928) }\end{array}$ & & & \\
\hline $\begin{array}{l}\text { Fras Herreds Sparekasse, } \\
\text { Rudding (1872) }\end{array}$ & \multicolumn{2}{|c|}{ 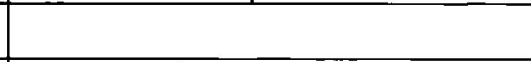 } & $\begin{array}{l}\text { Fros Herreds } \\
\text { Sparekasse }\end{array}$ \\
\hline $\begin{array}{l}\text { Broager Spare- og Laanekasse } \\
(1845)\end{array}$ & \multicolumn{2}{|c|}{ 2004: Navneandret til Broager Sparekasse } & $\begin{array}{l}\text { Broager } \\
\text { Sparekasse }\end{array}$ \\
\hline Visby Sogns Sparekasse (1873) & \multirow{2}{*}{\multicolumn{2}{|c|}{ 1971: Sammensluttet til Sparekassen Bredebro }} & $\begin{array}{l}\text { Sparekassen } \\
\text { Bredebro }\end{array}$ \\
\hline $\begin{array}{l}\text { Bredebro-Ballum Sparekasse } \\
\text { (1875) }\end{array}$ & & & \\
\hline $\begin{array}{l}\text { Tandslet Andelskasse (1896/ } \\
1921)\end{array}$ & $\begin{array}{l}\text { 1986: Tilsluttet } \\
\text { Sammen- } \\
\text { slutningen Danske } \\
\text { Andelskasser (SDA) }\end{array}$ & \multirow[t]{2}{*}{$\begin{array}{l}\text { 20)7: Sammensluttet til } \\
\text { Andelskassen } \\
\text { Swnderiylland } \\
\text { (Sisnderborg) }\end{array}$} & \multirow[t]{2}{*}{$\begin{array}{l}\text { Andelskassen } \\
\text { Sanderjylland } \\
\text { (SDA) }\end{array}$} \\
\hline $\begin{array}{l}\text { Tinglev Andelskasse (1900/ } \\
\text { 1921) }\end{array}$ & do. & & \\
\hline $\begin{array}{l}\text { Asserballeskov Andelskasse } \\
(1402 / 1921)\end{array}$ & do. & \multirow[t]{2}{*}{$\begin{array}{l}\text { 1994: Sammensluttet til } \\
\text { Asserballeskov-Sundeved } \\
\text { Andelskasse } \\
\text { 2(101: Navnexndret til } \\
\text { Andelskassien Alssund } \\
\text { (Augustenborg) }\end{array}$} & \multirow[t]{2}{*}{$\begin{array}{l}\text { Andelskassen } \\
\text { Alssund (SDA) }\end{array}$} \\
\hline $\begin{array}{l}\text { Sundeved Andelskasse (1903/ } \\
1921)\end{array}$ & do. & & \\
\hline
\end{tabular}

Anm.: Institutternes stiftelsesăr er anfort i parentes efter navnet i 1968-kolonnen.

24 sknderiyske pengeinstitutter - seks banker, 14 sparekasser og fire andelskasser - er i lobet af perioden 1968-2009 blevet til otte - tre banker, tre sparekasser og to andelskasser - med hjemsted i landsdelen. 
Bilagsskema 2: Senderiyske banker, sparekasser og andelskasser 1968, der i 2009 er del af pengeinstitutter hjemmehorende uden for Sonderjylland

\begin{tabular}{|c|c|c|c|}
\hline Sonderjyske pengein- & \multicolumn{2}{|c|}{ Sammenslutninger/overtagelser/navneæend ringer 1968-2009 } & Status 2009 \\
\hline $\begin{array}{l}\text { Spare- og Laanekassen } \\
\text { for Logumkloster og } \\
\text { Omegn (1821) }\end{array}$ & \multirow[t]{2}{*}{$\begin{array}{l}\text { 2003: Sammensluttet til Lo- } \\
\text { gumkloster Sparekasse }\end{array}$} & \multirow[t]{2}{*}{$\begin{array}{l}\text { 2009: Overtaget af Den Jyske Spare- } \\
\text { kasse (Grindsted) }\end{array}$} & \multirow[t]{2}{*}{$\begin{array}{l}\text { Den Jyske Spa- } \\
\text { rekasse }\end{array}$} \\
\hline $\begin{array}{l}\text { Privat Spare- og Laane- } \\
\text { kasse i Ravsted (18t-4) }\end{array}$ & & & \\
\hline $\begin{array}{l}\text { Banken for Jels og Om- } \\
\text { egn (1907) }\end{array}$ & $\begin{array}{l}\text { 1970: Sammensluttet med } \\
\text { Den Danske Landmands- } \\
\text { bank }\end{array}$ & \multirow[t]{3}{*}{$\begin{array}{l}\text { 1976: Den Danske Landmandsbank } \\
\text { endrer navn til Den Danske Bank. } \\
\text { 2000: navneændring til Danske Bank }\end{array}$} & \multirow[t]{16}{*}{ Danske Bank } \\
\hline Skærbæk Bank (1920) & $\begin{array}{l}\text { 1970: Sammensluttet med } \\
\text { Den Danske Landmands- } \\
\text { bank }\end{array}$ & & \\
\hline $\begin{array}{l}\text { Haderslev Creditbank } \\
\text { (1875) }\end{array}$ & $\begin{array}{l}\text { 1985: Sammensluttet med } \\
\text { Den Danske Bank }\end{array}$ & & \\
\hline $\begin{array}{l}\text { Haderslev Bys Spare- } \\
\text { og Laanekasse (1819) }\end{array}$ & $\begin{array}{l}\text { 1971: Sammensluttet med } \\
\text { Sparekassen Haderslev } \\
\text { 1971: Sammensluttet med } \\
\text { Sparekassen Haderslev } \\
\end{array}$ & $\begin{array}{l}\text { 1972: Sparekassen Haderslev indgår i } \\
\text { sammenslutningen Sparekassen } \\
\text { Sydjylland med hjemsted i Vejle. } \\
\text { 1991: Sparekassen Sydjylland sam- } \\
\text { mensluttes med Bikuben, der i } 1945 \\
\text { fusionerer med Girobank og andrer } \\
\text { navn til BG Bank. } \\
\text { 2001: BC, Bank sammensluttes med } \\
\text { Danske Bank. }\end{array}$ & \\
\hline $\begin{array}{l}\text { Sparekassen for } \\
\text { Haderslev Byes Om- } \\
\text { egn (1856) }\end{array}$ & \multirow{4}{*}{$\begin{array}{l}\text { 1971: Sammensluttet med } \\
\text { Sparekassen Haderslev } \\
\text { 1971: Sammensluttet med } \\
\text { Sparekassen Haderslev }\end{array}$} & \multirow[b]{5}{*}{$\begin{array}{l}\text { 1975: Sammensluttet med Sparekas- } \\
\text { sen Sydjylland } \rightarrow \text { Bikuben }\end{array}$} & \\
\hline $\begin{array}{l}\text { Haderslev Amts Spare- } \\
\text { kasse (1901) }\end{array}$ & & & \\
\hline $\begin{array}{l}\text { Agerskov Sparekasse } \\
(1863)\end{array}$ & & & \\
\hline $\begin{array}{l}\text { Toftlund og Omegns } \\
\text { Sparekasse }(1872)\end{array}$ & & & \\
\hline $\begin{array}{l}\text { Sparekassen for Chri- } \\
\text { stiansfeld og Omegn } \\
\text { (1872) }\end{array}$ & & & \\
\hline $\begin{array}{l}\text { Spare- og Laanekassen } \\
\text { for Ulkebol Sugn } \\
(1867)\end{array}$ & & \multirow{4}{*}{$\begin{array}{l}\text { 1969: Sammensluttet med Bikuben } \\
\text { 1972: Sammensluttet med Bikuben }\end{array}$} & \\
\hline $\begin{array}{l}\text { Skodborg og Omegns } \\
\text { Spare- Og Laanekasse } \\
\text { (1n84) }\end{array}$ & & & \\
\hline $\begin{array}{l}\text { Spare- og Laanekassen } \\
\text { for Skarbæk og Om- } \\
\text { egn }(1860)\end{array}$ & \multirow[t]{2}{*}{$\begin{array}{l}\text { 1972: Sammensluttet til } \\
\text { Sparekassen Skærbæk }\end{array}$} & & \\
\hline $\begin{array}{l}\text { Spare- og Laanekassen } \\
\text { for Dustrup Sogn } \\
\text { (1898) }\end{array}$ & & & \\
\hline $\begin{array}{l}\text { Sparekassen for Hojer } \\
\text { og Omegn (1843) }\end{array}$ & \multirow[t]{2}{*}{$\begin{array}{l}\text { 1973: Sammensluttet til } \\
\text { Sparekassen Højer }\end{array}$} & \multirow[t]{3}{*}{ 1990: Sammensluttet med Bikuben } & \\
\hline $\begin{array}{l}\text { Daler Sogns Sparekas- } \\
\text { se (1883) }\end{array}$ & & & \\
\hline $\begin{array}{l}\text { Emmerlev Sogns Spa- } \\
\text { re- og Laanekasse } \\
(1876)\end{array}$ & $\begin{array}{l}\text { 1973: Sammensluttet med } \\
\text { Sparekassen Højer }\end{array}$ & & \\
\hline Haderslev Bank (1875) & $\begin{array}{l}\text { 1970: Sammensluttet med } \\
\text { Privatbanken }\end{array}$ & \multirow[t]{2}{*}{$\begin{array}{l}\text { Privatbanken indgik i } 1989 \text { i Uni- } \\
\text { bank-sammenslutningen, som i } 1999 \\
\text { blev en del af Nordea }\end{array}$} & \multirow[t]{2}{*}{ Nordea } \\
\hline Gram Bank (1920) & $\begin{array}{l}\text { 1970: Sammensluttet med } \\
\text { Privatbanken }\end{array}$ & & \\
\hline $\begin{array}{l}\text { Romo Andelskasse } \\
(1904 / 1921)\end{array}$ & $\begin{array}{l}\text { 1986: Tilsluttet Sammen- } \\
\text { slutningen Danske Andels- } \\
\text { kasser (SDA) }\end{array}$ & $\begin{array}{l}\text { 2006: Sammensluttet med Jernved og } \\
\text { Omegns Andelskasse (Gredstedbro) } \\
\text { til Jernved-Rımb Andelskasse }\end{array}$ & $\begin{array}{l}\text { Jernved-Romo } \\
\text { Andelskasse } \\
\text { (SDA }\end{array}$ \\
\hline
\end{tabular}

Anm.: Institutternes stiftelsesár er anfort i parentes efter navnet i 1968-kolonnen.

21 sonderiyske pengeinstitutter - fem banker, 15 sparekasser og en andelskasse - er i lobet af perioden 1968-2009 gaet op i fire institutter, hijemmehorende uden for landsdelen - to storbanker, en sparekasse og en andelskasse. 


\section{LITTERATUR OG KILDER}

Axelsen Drejer, A.: Andelskasserne gennem et halvt århundrede. København 1966.

Baldvinsson, Cato m.fl.: Dansk bankvæsen. 5. udgave. Kobenhavn 2005.

Beretninger fra Finanstilsynet vedrørende Pengeinstitutter (siden 1988), vedrørende Banker og sparekasser (1975-87) samt fra Tilsynet med banker og sparekasser vedr. dels banker, dels sparekasser (indtil 1975).

Bøegh Nielsen, Peter: Fra sognesparekasse til landssparekasse. SDC 1997.

Danske bank- og sparekassepladser, udvalgte årgange siden 1965. De årlige oversigtsværker blev frem til slutningen af 1980'erne udgivet af Provinsbankforeningen, hhv. Sparevirkes Forlag, og siden 1991 af forlaget Dataform.

Eskesen, Lars: "20 år i de danske sparekassers historie 1970-89 «. Bidrag til Festskrift til Laurits Ringgaard, s. 87-94. Kobenhavn 1989.

Fode, Henrik: J.A.K. Jord. Arbejde. Kapital - en bevægelse i og med tiden. Arhus 2008.

GarantInformation april 2008 fra Folkesparekassen

Hagedorn C.C. og Korse Aug.: Broager Spare- og Laanekasse 1845-1995. Jubilæums-festskrift 1995.

Hansen, Jørgen: "Sparekassefusioner i Vejle Amt«. Bidrag til Vejle Amts Historiske Samfunds årbog 2006, s. 64-78.

Hansen, Per. H.: Da sparekasserne mistede deres uskyld. Odense Universitetsforlag 2001.

Harsberg, Vagn: De sønderjyske amtsråd indtil 1970. Afsnittet om kommunalreformen s. $295 \mathrm{ff}$. Sonderjyllands Amtsråd 1984.

Hübbe, Chr.: "De sønderjydske pengeinstitutter efter Genforeningen«. Sonderjyske Årboger 1931, s. 1-88.

Hübbe, Chr:: "Det nordslesvigske Pengevæsen «. Sønderjyske Arbøger 1910, s. 82-121.

Japsen, G.: De nordslesvigske sparekassers historie. Historisk Samfund for Sonderjylland 1970.

Jessen, Erik: Bare han får sin vilje. Erin- dringer. Historisk Samfund for Sonderjylland 1997.

Johansen, Alfred: Graasten Bank 19201970. Jubilæumsbog 1970.

Larsen, Kai Edvard: Folkebanken for Als og Sundeved 1909-1959. Jubilæumsbog. Sønderborg 1959.

Mikkelsen, Richard: Dansk Pengehistorie 1960-90. Bind 4. Danmarks Nationalbank 1993

Møller, Kristian: Fra idé til virkelighed. Jubilæumsbog. Andelsbanken 1975.

Maarup, Birgit: Ramo Andelskasses 100 års jubilæumsskrift. 2004

Ravn, Sven-Erik (red.): Kun dode fisk flyder med strommen. Jubilæumsbog udgivet af Frøs Herreds Sparekasse 1997.

Sammenslutningen Danske Andelskasser: 75 års jubilaum 1915-1990. SDA 1990.

Skifter Andersen, Erik: Erhvervsvirksomheder $i$ Aabenraa 1847-1997. Bind II: Handel og service. Aabenraa Handelsstandsforening 1997.

Sydbank $i 25$ år og Sydbanks historie. Artikler i EKKO, Sydbanks aktionær- og kundemagasin. Jubilæumsnummer 1995.

Sørensen, Edvard: Frøs Herreds Sparekasse 1872-1972. Jubilæumsbog. Rødding 1972.

Tandslet Andelskasse 1896-1996. Jubilæumsskrift 1996.

Trap, J.P.: Kongeriget Danmark. 4. udgave. Bind IX om bl.a. Senderjylland. København 1930.

Endvidere en lang række pengeinstitutog pengeinstitutrelaterede internethjemmesider.

Og ikke mindst rigtig mange imødekommende og gode mennesker - familie og venner, tidligere kolleger og samarbejdspartnere, nuværende pengeinstitutfolk, arkivarer, bibliotekarer m.fl. - som har hjulpet mig. Ingen nævnt ved navn - ingen glemt. En stor tak for gode råd og en masse spændende og nyttig information, som jeg håber at have håndteret efter fortjeneste. Eventuelle misforståelser og fejl er i hvert fald for min regning. 


\section{NOTER}

1. Bemandede betjeningssteder $=$ filialer er et nøglebegreb i nærværende artikel. Synonymt hermed benyttes som oftest betegnelsen (pengeinstitut-)afdeling samt andre/aldre begreber som agentur eller kontor/ kontorsted. »Bus-filialer (bank- og sparekassebussers holdepladser i oplandet, jf. også note 12) opfattes også som bemandede betjeningssteder.

2. De københavnske hovedbanker er Kjøbenhavns Handelsbank, Den Danske Landmandsbank og Privatbanken samt Andelsbanken.

3. Ved kommunalreformen i 1970 reduceredes antallet af sønderjyske kommuner således eksempelvis fra 120 til 23, jf. Harsberg (1984, s. 307-08).

4. Kjøbenhavns Handelsbank erhvervede ved Genforeningen den tyske Schleswig-Holsteinische Banks seks filialer i Nordslesvig - i Haderslev, Aabenraa, Senderborg, Gråsten, Tønder og Toftlund. Hübbe (1931, s. 15-16) skriver herom: »Dette var selvfølgelig et stort plus for Handelsbanken straks fra første fæerd ved Genforeningen at kunne glide ind $i$ en gammel forretning med en over hele Sønderjylland udbredt stor kundekreds; og det står også som en uomtvistelig kendsgerning, at Handelsbanken ... er bleven en meget betydende faktor indenfor sonderjydsk bankvirksomhed. Overalt på de ovennæunte pladser sidder Handelsbanken $i$ egne velindrettede bankbygninger og leder ud herfra sine forretninger med egnens folk på et godt og sundt forretningsgrundlag."

5. Se f.eks. Bregh Nielsen (1997, s. 14 ff).

6. I 1930'erne nedlagdes lokale sparekasser i Bylderup, Højst, Tinglev og Hygum, i 1940'erne i Bjolderup og Lejt, og i tiăret op til 1968 sparekasserne i Norre Logum, Nybøl, Ballum, Padborg og Kliplev, jf. Japsen (1970, s. 322 og 328-29), der herom skriver: "Små sparekassers nedlæg- gelse eller sammensmeltning med storre sparekasser havde man kendt helt fra århundredets første årti. Forhold af denne art var imidlertid af meget ringe betydning for sparekassernes udvikling $i$ almindelighed $«$.

7. De tre sønderjyske banker, der ophorte i perioden $1930-68$, var $\mathrm{Nu}$ strup Bank, som presset af krisen likvideres i 1932, Rødding Bank, der i 1948 bliver en del af Andelsbanken, og Løgumkloster Bank, der i 1963 overtages af Kjøbenhavns Handelsbank.

8. Politikerne viste også på kort sigt forståelse for behovet for konsolidering ved allerede $i 1961$ at åbne op for, at antallet af medlemmer af en sparekasses direktion kunne overstige tre. Det var væsentligt, fordi de fusioner og sammenslutninger, der var på tegnebrættet, helt overvejende var af den "venskabelige art «, og bl.a. lagde op til, at alle hidtidige direktører - naturligvis(!) - skulle med i det fortsættende instituts direktion. Den frrste egnssparekasse, der herefter så dagens lys - med fem direktionsmedlemmer - var Frederiksborg Amts Sparekasse i Nordsjælland, jf. Bøegh Nielsen (1997, kap. 1).

9. Omstruktureringsprocessen blev på forskellig vis understøttet af institutternes fælles interesseorganisationer - Danmarks Sparekasseforening og De danske Provinsbankers Forening. Sidstnæunte opererede således i slutningen af 1960'erne med et konsulenthold, der med udgangspunkt $i$ et fælles koncept rådgav om og bistod med lokalbankernes sammenslutninger til egns- og regionalbanker.

10. Bikubens overtagelse af J.A.K. Bank var den forste markante bank-sparekasse-fusion. Den blev gennemført uden store sværdslag - i modsætning til den samtidigt planlagte fusion mellem Privatbanken og Sparekassen Nordjylland, der faldt på de endnu dengang herskende organisatoriske holdninger til for- 
skelle mellem banker og sparekasser, jf. bl.a. Bøgh Nielsen (1997, kap. 7) og Per H. Hansen (2001, s. 138 ff).

11. Ledelsen i Løgumkloster Sparekasse havde til generalforsamlingen i marts 1976 indstillet en sammenslutning med Sparekassen Sydjylland. Forslaget faldt med den snævrest tænkelige margin, og sparekassen i Logumkloster forblev selvstændig frem til 2009.

12. Holdepladser for bank- og sparekassebusser - "bus-filialer « - var et fleksibelt og billigt alternativ til den traditionelle bankfilial, som så dagens lys i slutningen af 1950 'erne og var et meget anvendt instrument $i$ den øgede konkurrence om nærhed og synlighed overfor privatkunderne $i$ de efterfølgende årtier. "Bus-filialformen " toppede omkring 1980 med flere end 200 ekspeditionssteder på landsplan - over fem \% af det samlede antal bank-og sparekassepladser. Nye selvbetjeningsformer svækkede sammen med vigende befolkning $i$ de betiente yderdistrikter $i$ lobet af 1980 'erne forretningsgrundlaget for bus-filialerne, som fik dødsstodet med pc- og netbanking fra 1990'erne. Mere om bus-filialerne på Dansk Pengemuseums hjemmeside på http:/ / www.industrimuseet.dk.

13. Sydjydsk Landmandsbank i Ribe var repræsenteret i det nordvestligste hjørne af Sønderjylland, i grænseområdet mellem det gamle Tønder Amt og det gamle Ribe Amt, i Sdr. Hygum og Rejsby samt i Hviding, Spandet og Roager. Ved amtskommunalreformen i 1970 blev de tre sidstnæunte sogne en del af Ribe Amt, og de derværende bankfilialer falder dermed principielt ud af rammen for nærværende beskrivelse. De er dog med taget i oversigten i skema 1 og 2 og figur 2. Filialerne, som fra 1970 var overtaget af Provinsbanken, nedlægges alle i lobet af 1980 'erne. Grænsedragningen i 1970 mellem Sonderjylland og amterne nord for indebar også, at sognene Hejls, Taps og Vej- strup blev en del af den nye Christiansfeld kommune og dermed kom med i Sonderjyllands Amt. Sdr. Bjært og Vejstrup Sognes Sparekasses afdelinger i Hejls og Vejstrup blev således i 1970 sønderjyske, og det samme gælder Sparekassen for Christiansfeld og Omegns afdelinger i Sjølund og Taps. Sdr. Bjært/Vejstrup-sparekassen blev i 1971 overtaget af Spareog Laanekassen for Kolding By og Omegn (Kolding Sparekasse, senere Bikuben) og Christiansfeld-sparekassen i 1975 af Sparekassen Sydjylland. De 4 nævnte nordøst-sønderjyske filialer, der alle var nedlagt inden udgangen af 1980'erne, er også medtaget $\mathrm{i}$ oversigten i skema 1 og 2 og figur 2. Disse "grænsetilfælde « medvirker til »slør « i det her rapporterede samlede antal sønderjyske pengeinstitutafdelinger.

14. Forholdene i den restriktive kreditpolitiks og udlånsloftets epoke frem til begyndelsen af 1980'erne er belyst bl.a. hos Mikkelsen (1993, kap. 5) og - specielt vedrørende sparekasserne - hos Eskesen (1989, s. 90-92)).

15. Sydbanks kraftige ekspansionsaktivitet uden for det gamle hjemområde fra og med netop dette tidspunkt, først i 1980'erne, skal også ses i sammenhæng med, at Regional Bankerne - en forening, som Sydbank siden 1970 havde været med i - ændrede karakter fra et håndfast geografisk forretningsmæssigt kartel til en bankpolitisk samarbejdsorganisation. Det oprindelige idégrundlag for Regional Bankerne fik sit forste alvorlige skud for boven, da foreningsmedlemmet Jyske Bank i 1980 overtog den landsdækkende Finansbanken. Jyske Bank måtte ganske vist forlade samarbejdet; men det skete slog hul på fællesskabet, som i de følgende år blev løsere. Det åbnede nye perspektiver for foretagsomme institutter som Sydbank.

16. Union-Bank er etableret i 1927 på grundlag af danskhedens siden 1875 virkende Spare- og Laanekas- 
sen for Flensborg og Omegn. Aktionærkredsen bestod fra starten af forretningsdrivende i Flensborg, landmænd og private personer, hvis fælles princip var at sikre videreførelsen af et selvstændigt pengeinstitut med stærk dansk indflydelse i regionen. I dag er UnionBanks aktionærkreds jævnt fordelt på begge sider af grænsen. Det skal tilføjes, at Danmarks Nationalbank helt tilbage i 1844 etablerede en filial i Flensborg, og at denne filial forst blev endeligt afviklet i 1939.

17. Der henvises vedrorende sparekassernes mulighed for overgang til aktieselskabsformen i 1988 til Per H. Hansen (2001, s. 271 ff.).

18. Af Baldvinsson m.fl. (2005, s. 22 ff.) fremgår, at der $\mathrm{i}$ begyndelsen af 90 'erne omdannedes 10 sparekasser til aktieselskaber, herunder de daværende fem største, svarende til $85 \%$ af sparekassernes samlede balance.

19. Indtil 2009, da Den Jyske Sparekasse (fra Grindsted) overtog Sparekassen Løgumkloster.

20. Alm. Brand Bank etablerede i anden halvdel af 90'erne bankkontorer i Aabenraa, Haderslev og Sonderborg, og Sparbank (Vest i Skive) i Haderslev og Sonderborg. I 2009 har Alm. Brand Bank fortsat bankkontor i Sonderborg og Sparbank i Haderslev.

21. Danske Bank kan via overtagelsen af BG Bank også levere bankmæssig kundeekspedition på landets posthuse. Baggrunden herfor er Girobanks udskillelse i 1991 fra postvæsenet og efterfølgende sammenslutning med Bikuben. I 1996 indgik Post Danmark en samarbejdsaftale med BG Bank om, at Post Danmark på vegne af banken udfører finansielle serviceydelser på posthusene.

22. Andelskasserne er lokale, solidarisk-kundeejede institutter, oprindeligt med begrænsede aktivitetsmuligheder. Siden 1980'erne har andelskasserne aktivitetsmæssigt været at sidestille med banker og sparekasser. I 1986 indgik de fleste danske andelskasser - dengang i alt 47 - i paraplyorganisationen Sammenslutningen Danske Andelskasser (SDA). Reelt er medlemsandelskasserne herefter afdelinger af koncernselskabet SDA. De enkelte andelskasser optræder dog fortsat ganske selvstændigt under eget navn. Vedrarende andelskasserne generelt henvises bl.a. til 75-års jubilæumsskriftet (1915-1990), udgivet af SDA, og til Axelsen Drejer (1966).

23. Vedrørende J.A.K.-bevægelsen henvises til Henrik Fode (2007).

24. Der henvises bl.a. til Mikkelsen (1993, kap. 9).

25. Jf. Kai Edvard Larsen (1959, s. 27-35 og 97-100).

26. Det var ikke mindst daværende borgmester i Aabenraa og formand for Den Nordslesvigske Folkebank, Erik Jessen, og borgmester i Tønder og bankdirektør i Tønder Landmandsbank, Johan Paulsen, der var Sydbank-sammenslutningens arkitekter og bagmænd. Se Erik Jessen (1997, s.390 ff.).

27. Foreningen De sønderjyske sparekasser blev oprettet i 1930'erne som et branchefælleskab for de sønderjyske sparekasser. Foreningen blev i 1960'erne omdrejningspunkt for initiativer, der skulle bidrage til, at de enkelte sparekasser, stottet af foreningen, kunne løse også større forretningsmæssige kreditformidlingsopgaver. 11967 optrappedes foreningens aktiviteter med en egentlig fællesorganisation omfattende en regionssekretær, der tog sig af fælles reklame, en lønmodtagerkonsulent og en skolekonsulent. I foreningens regi koordineredes også prisforhold og rentesatser. Foreningen blev, i en længere periode med deltagelse også af Sparekassen Sydjylland og Bikuben, opretholdt frem til 1990. Men dens rolle blev vel efterhånden mere "selskabelig " end forretningsorienteret - af den simple grund at medlemsinstitutterne i årenes løb i stigende grad opfattede hinanden som konkurrenter snarere end kol- 
leger. Den endelige nedlæggelse havde endvidere baggrund $i$ et svindende medlemstal, men også i konkurrencemyndighedernes vågnende interesse for foreningens mulige karakter af priskartel.
28. Jydske Tidendes Tønder-udgave 2. april 1976.

29. Nykredit har i 2008 overtaget Forstædernes Bank og er dermed på vej over i den fysiske - bemandet/ betjente - bankforretning. 